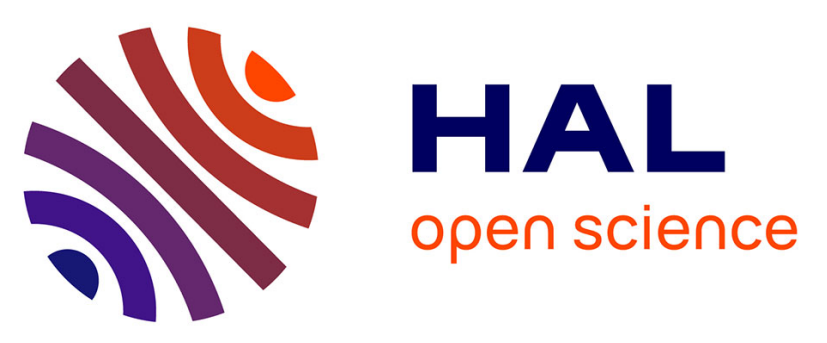

\title{
Ferrocene-Based Pincer Complexes of Palladium: Synthesis, Structures, and Spectroscopic and Electrochemical Properties
}

\author{
Avthandil Koridze, Sergey Kuklin, Aleksey Sheloumov, Fedor Dolgushin, \\ Veronika Yu. Lagunova, Irina Petukhova, Mariam Ezernitskaya, Alexander \\ Peregudov, Pavel Petrovskii, Evgenii Vorontsov, et al.
}

\section{To cite this version:}

Avthandil Koridze, Sergey Kuklin, Aleksey Sheloumov, Fedor Dolgushin, Veronika Yu. Lagunova, et al.. Ferrocene-Based Pincer Complexes of Palladium: Synthesis, Structures, and Spectroscopic and Electrochemical Properties. Organometallics, 2004, 23 (20), pp.4585-4593. 10.1021/om0497285 . hal-03280326

\section{HAL Id: hal-03280326 https://hal.science/hal-03280326}

Submitted on 8 Jul 2021

HAL is a multi-disciplinary open access archive for the deposit and dissemination of scientific research documents, whether they are published or not. The documents may come from teaching and research institutions in France or abroad, or from public or private research centers.
L'archive ouverte pluridisciplinaire $\mathbf{H A L}$, est destinée au dépôt et à la diffusion de documents scientifiques de niveau recherche, publiés ou non, émanant des établissements d'enseignement et de recherche français ou étrangers, des laboratoires publics ou privés. 


\section{Ferrocene - Based Pincer Complexes of Palladium: Synthesis, Structures, and Spectroscopic and Electrochemical Properties}

Avthandil A. Koridze*a,b, Sergey A. Kuklin ${ }^{\mathrm{a}}$, Aleksey M. Sheloumov ${ }^{\mathrm{a}}$, Fedor M. Dolgushin ${ }^{\mathrm{a}}$, Veronika Yu. Lagunova ${ }^{a}$, Irina I. Petukhova ${ }^{a}$, Mariam G. Ezernitskaya ${ }^{a}$,

Alexander S. Peregudov ${ }^{\mathrm{a}}$, Pavel V. Petrovskii ${ }^{\mathrm{a}}$, Evgenii V. Vorontsov ${ }^{\mathrm{a}}$, Miguel Baya ${ }^{\mathrm{c}}$, and Rinaldo Poli*c

${ }^{a}$ A.N. Nesmeyanov Institute of Organoelement Compounds, Russian Academy of Sciences, 28 Vavilov Street, 119991 Moscow, Russian Federation

${ }^{\mathrm{b}}$ I. Javakhishvili Tbilisi State University, 1 Chavchavadze Avenue, 380028 Tbilisi, Georgia ${ }^{\mathrm{c}}$ Laboratoire de Chimie de Coordination, 205 Route de Narbonne, 31077 Toulouse Cedex, France

Proofs to :

Avthandil Koridze

Tel. $+7(095) 1356416$

Fax. +7(095) 1355085

E-mail: koridze@ineos.ac.ru 


\section{Summary}

Palladium P,C,P pincer complexes based on ferrocene were synthesized for the first time. The reaction of 1,3-bis(dialkylphosphinomethyl)ferrocenes \{1,3$\left.\left(\mathrm{R}_{2} \mathrm{PCH}_{2}\right)_{2} \mathrm{C}_{5} \mathrm{H}_{3}\right\} \mathrm{Fe}\left(\mathrm{C}_{5} \mathrm{H}_{5}\right)\left(\mathbf{2 a}, \mathrm{R}=\mathrm{Pr}^{\mathrm{i}} ; \mathbf{2} \mathbf{b}, \mathrm{R}=\mathrm{Bu}^{\mathrm{t}}\right)$ with $\mathrm{PdCl}_{2}\left(\mathrm{NCPh}_{2}\right.$ in refluxing 2methoxyethanol leads to the corresponding pincer complexes $\operatorname{PdCl}[\{2,5-$ $\left.\left.\left(\mathrm{R}_{2} \mathrm{PCH}_{2}\right)_{2} \mathrm{C}_{5} \mathrm{H}_{2}\right\} \mathrm{Fe}\left(\mathrm{C}_{5} \mathrm{H}_{5}\right)\right]$ (3a, 3b). Ferrocene-based binuclear compound $\mathbf{3 b}$ reacts with $\left[\mathrm{Cp}_{2} \mathrm{Fe}_{\mathrm{PF}_{6}}\right.$ to form the ferrocenium-based pincer complex $\{\operatorname{PdCl}[\{2,5-$ $\left.\left.\left.\left(\mathrm{Bu}_{2}{ }_{2} \mathrm{PCH}_{2}\right)_{2} \mathrm{C}_{5} \mathrm{H}_{2}\right\} \mathrm{Fe}\left(\mathrm{C}_{5} \mathrm{H}_{5}\right)\right]\right\} \mathrm{PF}_{6}(\mathbf{4 b})$, and this is the first example of ferrocene-based phosphine chelate oxidation centered on the iron atom. Treatment of complexes 3a and $\mathbf{3 b}$ with $\mathrm{NaBH}_{4}$ in refluxing ethanol leads to the complexes $\operatorname{Pd}\left(\mathrm{BH}_{4}\right)[\{2.5-$ $\left.\left.\left(\mathrm{R}_{2} \mathrm{PCH}_{2}\right)_{2} \mathrm{C}_{5} \mathrm{H}_{2}\right\} \mathrm{Fe}\left(\mathrm{C}_{5} \mathrm{H}_{5}\right)\right] \quad\left(\mathbf{5 a}, \quad \mathrm{R}=\mathrm{Pr}^{\mathrm{i}} ; \quad \mathbf{5 b}, \quad \mathrm{R}=\mathrm{Bu}^{\mathrm{t}}\right)$, containing a $\mathrm{BH}_{4}{ }^{-}$group coordinated to the metal in the rarely occurring unidentate mode. The structures of $\mathbf{3 a}$, $\mathbf{3 b}$, and $\mathbf{5 b}$ were confirmed by X-ray analyses. Cyclic voltammetric investigations of complexes $\mathbf{2 a}, \mathbf{2 b}, \mathbf{3 a}$, and $\mathbf{3 b}$ are also reported. The structural and spectroscopic features of the palladium ferrocene-based pincer complexes are discussed and compared with those of related compounds. 


\section{Introduction}

Transition metal complexes with tridentate monoanionic ligands, so-called "pincer" ligands $\mathbf{1}$, of general formula $\left[2,6-\left(\mathrm{ECH}_{2}\right)_{2} \mathrm{C}_{6} \mathrm{H}_{3}\right]$, where $\mathrm{E}$ is a neutral two-electron donor such as $\mathrm{NR}_{2}, \mathrm{PR}_{2}, \mathrm{AsR}_{2}, \mathrm{OR}$, or $\mathrm{SR}$, show interesting and rich chemistry ${ }^{2}$. The first pincer complexes were synthesized on the base of 1,3-bis(di-tert-butylphosphinomethyl)benzene by C.M. Moulton and B.L.Shaw ${ }^{\mathbf{3}}$ as early as in 1976, but interest and activity in this area have rapidly increased especially during the past decade. The presence of one metal-carbon $\sigma$ bond and two chelating donor atoms are responsible for the high thermal stability of pincer complexes. The highly protective environment for the multi-bound metal and possibilities to tune the properties of the metal center gave impetus to extensive research on the use of pincer complexes as homogeneous catalysts ${ }^{2}$, as well as crystalline switches and sensors ${ }^{2 \mathbf{c}}$.

Pincer complexes catalyse various transformations of organics, such as Kharasch addition $^{4}$, Heck olefin arylation ${ }^{5}$, Suzuki aryl coupling6, enantioselective aldol type condensation of methyl isocyanoacetate and aldehydes ${ }^{7}$, transfer hydrogenation of ketones ${ }^{\mathbf{8}}$, polymerization of phenylacetylene ${ }^{9}$, and alkane dehydrogenation ${ }^{2 d, 10}$. It is remarkable that palladium P,C,P pincer complexes catalyze the Heck reaction with turnover number (TON) as high as $500000^{5 a}$. Hydrido iridium P,C,P pincer complexes proved to be the most active (TON up to 1200) among all known homogeneous catalysts for alkane dehydrogenation ${ }^{10 e}$.

Although impressive progress has been achieved in this area, the majority of pincer complexes cannot find industrial application for a variety of reasons. For example, the reaction rates are still insufficient; asymmetric aldol addition gives only moderate (65\%) e.e.s of the product; the rates of alkane dehydrogenation by iridium complexes are also insufficient; product inhibition and isomerization of primarily formed 1-alkenes into internal isomers take place. 
It is obvious that a search for approaches to the design of novel pincer complexes is a topical problem. One way of solving this problem is to substantially modify the pincer ligand, including a change of its electronic and steric properties.

It is rather remarkable that there have been no reports until recently on attempts to design pincer complexes based on aromatic homocyclic system other than the benzene, viz, the cyclopentadienyl ring of metallocenes. At the same time, the design of conceptually novel binuclear pincer systems based on metallocene seems to be very attractive. We believe that metallocene-based pincer complexes of the $\mathbf{B}$ type could possess electronic and steric features which distinguish them from their benzene analogs $\mathbf{A}$, and are attractive from the viewpoint of their use in catalysis (Chart 1).

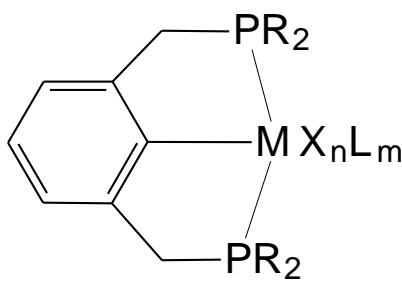

A

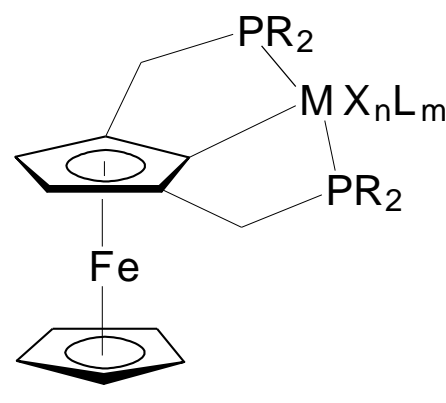

B

Chart 1

These features are as follows. ${ }^{11}$ First, the central atom of the metallocene unit in metallocene-based pincer complexes is located in the vicinity ( $\beta$-position) of the catalytic center, the chelated metal atom M; this arrangement can facilitate tuning of electronic effects on the atom $\mathrm{M}$ by varying the metallocene central atom (Fe, $\mathrm{Ru}$, and $\mathrm{Os}$ ). Second, the iron atom in ferrocene can be involved into a rapid and reversible redox reaction, thus providing an additional possibility to tune the electron density at the catalytic center. Third, the sandwich nature of ferrocene allows one to design planar-chiral molecules (the known benzene-based P,C,P chiral ligands usually possess elements of central chirality at the benzylic positions, which are remote from the catalytic center M), in which chirality of the $\mathrm{P}, \mathrm{C}, \mathrm{P}$ ' ligand results from the presence of different substituents at the $\mathrm{P}$ donor atoms; the presence of the $\mathrm{Fe}\left(\mathrm{C}_{5} \mathrm{H}_{5}\right)$ 
fragment provides the additional possibility to tune the stereochemistry around the catalytic center. It may prevent isomerization of 1-alkenes, primary products of the iridium-catalysed alkane dehydrogenation, into less valuable internal alkenes. It should be also noted that the iron group metallocenes possess high thermal stability.

The possibility to design metallocene-based P,C,P pincer complexes was not evident, since the $\mathrm{P}$ donor atoms in 1,3-bis(diorganylphosphinomethyl)metallocenes are more remote from each other than those in benzene analogs. Metallocene-based pincer complexes might be expected to be formed only at the expense of a deviation of the bond angles at the $\mathrm{C}(2)$ and $\mathrm{C}(5)$ centers in pincer complexes from the standard value of $126^{\circ}$ for the cyclopentadienyl ring.

In early 2002 , we published ${ }^{\mathbf{1 1}}$ preliminary results on the synthesis and X-ray structure of the first representative of ferrocene-based P,C,P pincer complexes, the rhodium derivative cis- $\mathrm{RhCl}_{2}(\mathrm{CO})\left[\left\{2,5-\left(\mathrm{Pr}_{2} \mathrm{PCH}_{2}\right)_{2} \mathrm{C}_{5} \mathrm{H}_{2}\right\} \mathrm{Fe}\left(\mathrm{C}_{5} \mathrm{H}_{5}\right)\right]$ (1) (Eq.1).

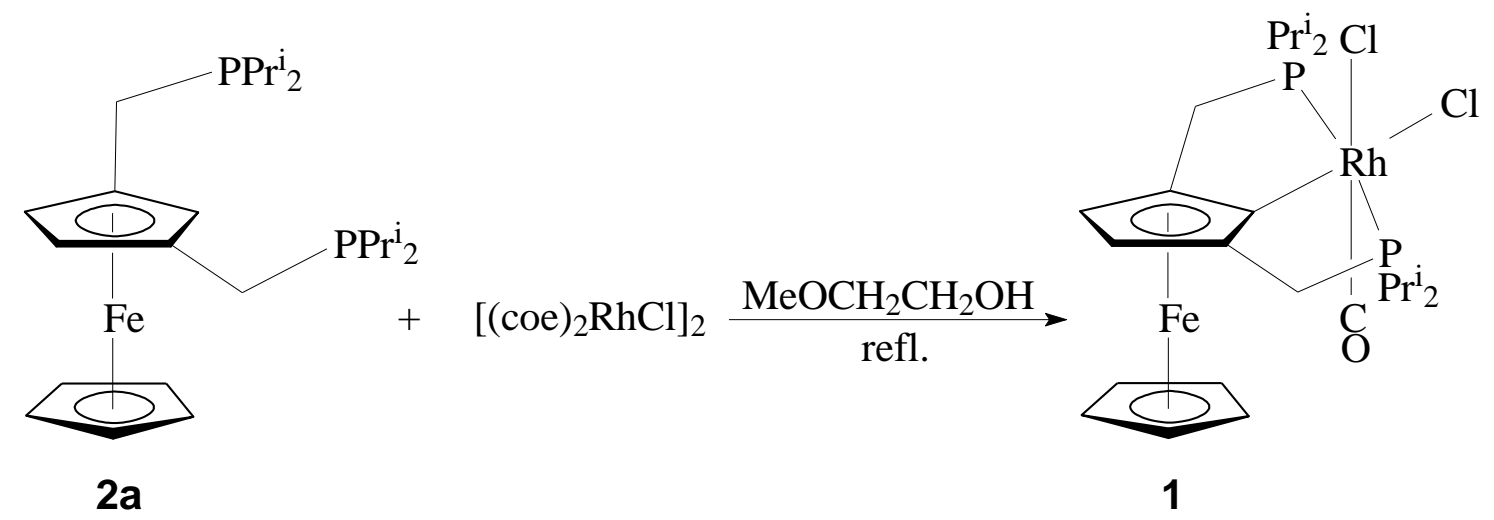

Simultaneously, G. van Koten and J.M. Brown with co-workers ${ }^{\mathbf{1 2}}$ published a brief report on the synthesis of the rhodium pincer complex $\operatorname{RhH}(\mathrm{Cl})[\{2,5-$ $\left.\left.\left(\mathrm{Bu}_{2}^{\mathrm{t}} \mathrm{PCH}_{2}\right)_{2} \mathrm{C}_{5} \mathrm{H}_{2}\right\} \mathrm{Fe}\left(\mathrm{C}_{5} \mathrm{H}_{5}\right)\right]$ (a mixture of endo- and exo-H isomers). Thus, it was demonstrated that it is possible to synthesized metallocene-based pincer complexes. As expected, the X-ray diffraction study of complex $\mathbf{1}$ revealed that the formation of the metallocene-based complex led to a decrease (by $\approx 5^{\circ}$ ) of the bond angles at $\mathrm{C}(2)$ and $\mathrm{C}(5)$ 
atoms in fused metallacycles as compared to the standard value. Other interesting structural features in view of the catalytic application of metallocene-based complexes have also been established. The formation of complex 1 gave impetus to a further search for procedures for the synthesis of precursors of metallocene-based pincer ligands such as $\mathrm{P}, \mathrm{CH}, \mathrm{P}$ and $\mathrm{P}, \mathrm{CH}, \mathrm{N}^{\mathbf{1 1}}$, and hydrido iridium P,C,P pincer complexes based on ferrocene and ruthenocene ${ }^{\mathbf{1 3 a}, \mathbf{b}}$.

Our interest in the generation of metallocene-based pincer complexes was stimulated by reports of Kaska, Jensen, and Goldman with co-workers on the extraordinary catalytic activity of iridium pincer complexes $\operatorname{IrH}_{2}\left[2,6-\left(\mathrm{R}_{2} \mathrm{PCH}_{2}\right)_{2} \mathrm{C}_{6} \mathrm{H}_{3}\right] \quad\left(\mathrm{R}=\mathrm{Bu}^{\mathrm{t}}, \mathrm{Pr}^{\mathrm{i}}\right)$ in alkane dehydrogenation ${ }^{\mathbf{1 0 f}, \mathbf{g}}$. It seemed extremely interesting to produce metallocene-based analogs of these complexes, $\operatorname{IrH}_{2}\left[\left\{2,5-\left(\mathrm{R}_{2} \mathrm{PCH}_{2}\right)_{2} \mathrm{C}_{5} \mathrm{H}_{2}\right\} \mathrm{M}^{\prime}\left(\mathrm{C}_{5} \mathrm{H}_{5}\right)\right]\left(\mathrm{M}^{\prime}=\mathrm{Fe}, \mathrm{Ru}\right)$, and to evaluate their properties as catalysts for the dehydrogenation of alkanes and organics containing alkyl groups ${ }^{13 a, b}$. Since accessibility of the catalytic center for substrates is one of the most important factors in catalysis, it was desirable to possess the X-ray structural data on the steric environment of the Ir atom in metallocene-based hydrido iridium complexes. Unfortunately, we failed to prepare single crystals of complexes $\operatorname{IrH}_{2}\left[{ }^{\mathrm{R}} \mathrm{P}, \mathrm{C}, \mathrm{P}^{\mathrm{M}}\right]$ and $\mathrm{IrH}_{4}\left[{ }^{\mathrm{R}} \mathrm{P}, \mathrm{C}, \mathrm{P}^{\mathrm{M}}\right]$ suitable for an X-ray diffraction study. For this reason, we have initiated the study of chloro palladium complexes, $\operatorname{PdCl}\left[\left\{2,5-\left(\mathrm{R}_{2} \mathrm{PCH}_{2}\right)_{2} \mathrm{C}_{5} \mathrm{H}_{2}\right\} \mathrm{Fe}\left(\mathrm{C}_{5} \mathrm{H}_{5}\right)\right]\left(\mathbf{3 a}, \mathrm{R}=\mathrm{Pr}^{\mathrm{i}} ; \mathbf{3 b}, \mathrm{R}=\mathrm{Bu}^{\mathrm{t}}\right)$ as model compounds. Besides, complexes $\mathbf{3 a}$ and $\mathbf{3 b}$ are of independent interest as potential catalysts for the Heck and related carbon-carbon coupling reactions.

This account represents the first full paper on metallocene-based P,C,P pincer complexes of platinum group metals and includes details of the synthesis of ferrocene-based P,CH,P diphosphines, P,C,P pincer complexes of palladium, their crystal structures, and spectroscopic and redox properties. Some of these results have been published as preliminary communication $^{\mathbf{1 3 c}, \mathbf{d}}$. 


\section{Results and Discussion}

\section{Synthesis of chloro palladium ferrocene-based $P, C, P$ pincer complexes}

The starting 1,3-bis(dialkylphosphinomethyl)ferrocenes $\quad\left\{1,3-\left(\mathrm{R}_{2} \mathrm{PCH}_{2}\right)_{2} \mathrm{C}_{5} \mathrm{H}_{3}\right\}-$ $\mathrm{Fe}\left(\mathrm{C}_{5} \mathrm{H}_{5}\right) \quad\left(\mathbf{2 a}, \quad \mathrm{R}=\mathrm{Pr}^{\mathrm{i}} ; \quad \mathbf{2 b}, \quad \mathrm{R}=\mathrm{Bu}^{\mathrm{t}}\right) \quad$ were obtained by the reaction of $1,3-$ bis(hydroxymethyl)ferrocene with the corresponding dialkylphosphines $\mathrm{HPR}_{2}$ in hot acetic acid. Cyclometallation of diphosphines $\mathbf{2 a}$ and $\mathbf{2} \mathbf{b}$ with $\mathrm{PdCl}_{2}(\mathrm{NCPh})_{2}$ in 2-methoxyethanol at $120^{\circ} \mathrm{C}$ gives chloro palladium pincer complexes $\mathbf{3 a}$ and $\mathbf{3 b}$, respectively (Eq.2).

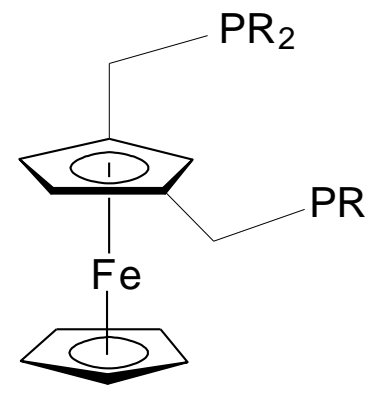

2a, $R=\operatorname{Pr}^{\mathrm{i}}$

2b, $R=\mathrm{Bu}^{\mathrm{t}}$

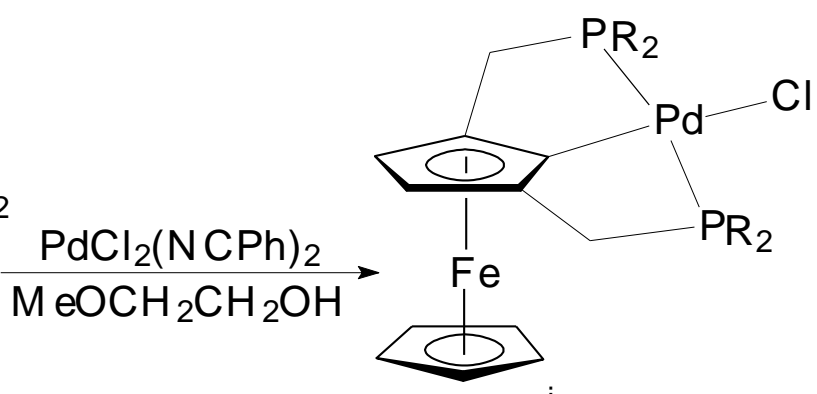

3a, $\mathrm{R}=\mathrm{Pr}^{\mathrm{i}}$

3b, $\mathrm{R}=\mathrm{Bu} \mathrm{t}^{\mathrm{t}}$

Chloro palladium complexes form orange air and thermally stable crystalline solids (they remain unchanged after heating in solution at $150^{\circ} \mathrm{C}$ for several hours). Compounds 3a and $\mathbf{3 b}$ were characterized by NMR and mass spectrometries and by elemental analysis. A single resonance was observed for the two equivalent phosphorus nuclei in the ${ }^{31} \mathrm{P}\left\{{ }^{1} \mathrm{H}\right\} \mathrm{NMR}$ spectrum, at $\delta 71.8(\mathbf{3 a})$ and $85.8 \mathrm{ppm}(\mathbf{3 b})$. In the ${ }^{1} \mathrm{H}$ NMR spectra, the resonances of the cyclopentadienyl protons of the ferrocene unit are revealed as two singlets of relative intensities of $5 \mathrm{H}$ and $2 \mathrm{H}$, indicating the cyclometalation of the substituted ring. The methylene protons of the $\mathrm{CH}_{2} \mathrm{PR}_{2}$ groups are nonequivalent and are revealed as a doublet of triplets. In the ${ }^{1} \mathrm{H}$ NMR spectrum of complex $\mathbf{3 b}$, the methyl protons of the tert-butyl groups gave two 
virtual triplets at $\delta 1.28\left({ }^{3} J_{\mathrm{PH}}=6.5 \mathrm{~Hz}, 18 \mathrm{H}\right)$ and $1.55\left({ }^{3} J_{\mathrm{PH}}=7.0 \mathrm{~Hz}, 18 \mathrm{H}\right)$, in accord with the expected structure. For complex 3a the methyl protons of the isopropyl groups are observed as three pseudo quadruplets at $\delta 1.07,1.33$, and $1.53 \mathrm{ppm}$ of relative intensities of $6 \mathrm{H}, 12 \mathrm{H}$, and $6 \mathrm{H}$, respectively. A similar spectral pattern was observed earlier ${ }^{11}$ for the isopropyl groups in the spectrum of complex $\mathbf{1}$. The ${ }^{13} \mathrm{C}\left\{{ }^{1} \mathrm{H}\right\}$ NMR spectrum of $\mathbf{3 b}$ is also in accordance with the expected structure, with the cyclopentadienyl resonances being observed at $\delta 114.28(\mathrm{t}$, $\left.J_{\mathrm{PC}}=20.0 \mathrm{~Hz}, 1 \mathrm{C}, \mathrm{C}(1)\right), 92.75\left(\mathrm{t}, J_{\mathrm{PC}}=13.9 \mathrm{~Hz}, 2 \mathrm{C}, \mathrm{C}(2,5)\right)$, and $63.76\left(\mathrm{t}, J_{\mathrm{PC}}=81 \mathrm{~Hz}, 2 \mathrm{C}\right.$, $\mathrm{C}(3,4))$.

Formation of complex $\left\{\mathrm{PdCl}\left[\left\{2,5-\left(\mathrm{Bu}_{2}{ }_{2} \mathrm{PCH}_{2}\right) \mathrm{C}_{5} \mathrm{H}_{2}\right\} \mathrm{Fe}\left(\mathrm{C}_{5} \mathrm{H}_{5}\right)\right]\right\} \mathrm{PF}_{6}(4 \mathrm{~b})$. Complex 3b reacts with the equivalent amount of $\left[\mathrm{Cp}_{2} \mathrm{Fe}\right] \mathrm{PF}_{6}$ in methylene chloride at room temperature to form the green ferrocenium-based pincer complex $\{\operatorname{PdCl}[\{2,5-$ $\left.\left.\left.\left(\mathrm{Bu}_{2}^{\mathrm{t}} \mathrm{PCH}_{2}\right)_{2} \mathrm{C}_{5} \mathrm{H}_{2}\right\} \mathrm{Fe}\left(\mathrm{C}_{5} \mathrm{H}_{5}\right)\right]\right\} \mathrm{PF}_{6}(4 \mathbf{b})$ in $\approx 80 \%$ yield (Eq.3). This is the first example of ferrocene-based phosphine chelate oxidation centered on the iron atom.

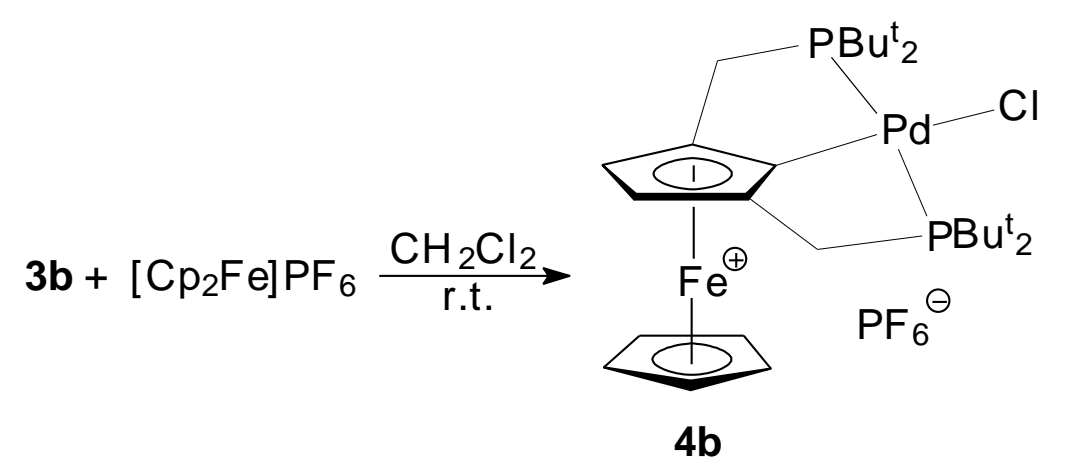

Complex $\mathbf{4 b}$ is poor soluble in chloroform, but readily soluble in methylene chloride. The NMR spectral data of $\mathbf{4 b}$ indicate its paramagnetic character. In the ${ }^{1} \mathrm{H}$ NMR spectrum, the methyl protons of the tert-butyl groups are observed at $\delta-10.24$ and $7.30 \mathrm{ppm}$, and the methylene group protons of $\mathrm{CH}_{2} \mathrm{PBu}_{2}^{\mathrm{t}}$ appear at $\delta-115.49$ (very broad) and -25.87 (broad) ppm. In the ${ }^{31} \mathrm{P}\left\{{ }^{1} \mathrm{H}\right\}$ NMR spectrum of $\mathbf{4 b}$, there is a singlet at $\delta 93.9 \mathrm{ppm}\left(2 \mathrm{P}, \mathrm{PBu}_{2}^{\mathrm{t}}\right)$ and a septet at $-150.0 \mathrm{ppm}\left(1 \mathrm{P}, \mathrm{PF}_{6}, J_{\mathrm{PF}}=709.5 \mathrm{~Hz}\right)$. The ferrocenium nature of complex $\mathbf{4 b}$ follows 
also from its electrochemical behaviour as compared to the redox characteristics obtained from an electrochemical study of complex $\mathbf{3 b}$ (see below).

Formation of complexes $\operatorname{Pd}\left(\mathrm{BH}_{4}\right)\left[\left\{2,5-\left(\mathrm{R}_{2} \mathrm{PCH}_{2}\right)_{2} \mathrm{C}_{5} \mathrm{H}_{2}\right\} \mathrm{Fe}\left(\mathrm{C}_{5} \mathrm{H}_{5}\right)\right]\left(5 \mathrm{a}, \mathrm{R}=\mathrm{Pr}^{\mathrm{i}} ; 5 \mathrm{~b}\right.$, $\mathbf{R}=\mathbf{B} \mathbf{u}^{\mathbf{t}}$ ). Our initial attempts to synthesize hydrido palladium complex by the reaction of $\mathbf{3 b}$ with $\mathrm{LiAIH}_{4}$ was unsuccessful because the reaction was accompanied by the destruction of the pincer complex to form free diphosphine $\mathbf{2 b}$. However, we found that when $\mathrm{NaBH}_{4}$ was used as a reducing agent, both chloro complexes, $\mathbf{3 a}$ and $\mathbf{3 b}$, yield the corresponding tetrahydroborate derivatives of palladium, complexes $\operatorname{Pd}\left(\mathrm{BH}_{4}\right)[\{2,5-$ $\left.\left.\left(\mathrm{R}_{2} \mathrm{PCH}_{2}\right)_{2} \mathrm{C}_{5} \mathrm{H}_{2}\right\} \mathrm{Fe}\left(\mathrm{C}_{5} \mathrm{H}_{5}\right)\right]\left(\mathbf{5 a}, \mathrm{R}=\mathrm{Pr}^{\mathrm{i}} ; \mathbf{5 b}, \mathrm{R}=\mathrm{Bu}^{\mathrm{t}}\right)(\mathrm{Eq} .4)$.

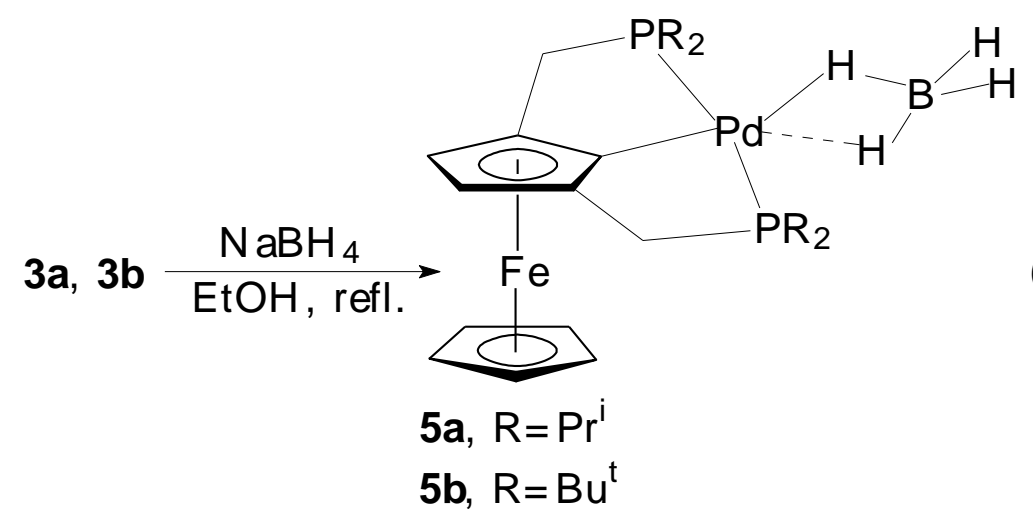

The ${ }^{1} \mathrm{H}$ and ${ }^{31} \mathrm{P}\left\{{ }^{1} \mathrm{H}\right\}$ NMR spectral data indicate that the tridentate $\mathrm{P}, \mathrm{C}, \mathrm{P}$ pincer ligand is retained in complexes $\mathbf{5} \mathbf{a}$ and $\mathbf{5} \mathbf{b}$. The presence of the $\mathrm{BH}_{4}{ }^{-}$ligand is evident from the ${ }^{1} \mathrm{H}$ and ${ }^{11} \mathrm{~B}$ NMR spectra. The ${ }^{1} \mathrm{H}$ NMR spectrum of $\mathbf{5 b}$ contains a very broad pseudo quadruplet at $\delta-0.50 \mathrm{ppm}\left(J_{\mathrm{BH}}=97, J_{\mathrm{BH}}=55 \mathrm{~Hz}\right)$. The ${ }^{11} \mathrm{~B}$ NMR spectrum consists of a quintet at $\delta-37.28$ ppm, with coupling constant $J_{\mathrm{BH}}=83.1 \mathrm{~Hz}$; the multiplicity of the signal indicates fast averaging of all four $\mathrm{H}$ atoms bound to the B atom. The IR spectrum of $\mathbf{5 b}$ contains the B-H stretching bands at 2380(sh), 2369(v.s.) and 2293(s), and an intense absorption at $1064 \mathrm{~cm}^{-1}$ $\left(\mathrm{BH}_{3}\right.$ deformation); the latter band is characteristic of the unidentate $\mathrm{BH}_{4}{ }^{-}$ligand ${ }^{\mathbf{1 4}}$.

It is known that the $\mathrm{BH}_{4}{ }^{-}$ion can form transition metal complexes, in which it coordinates the metal by three, two, and one hydrogen atoms ${ }^{\mathbf{1 4}}$. While the two first bonding 
modes are quite common, the unidentate coordination mode very rarely occurs. To our knowledge, palladium complexes with the $\eta^{1}-\mathrm{BH}_{4}$ ligand have not been characterized earlier.

X-ray diffraction study of complexes $\mathbf{3 a}, \mathbf{3 b}$, and $\mathbf{5 b}$. It was of interest to study the structures of ferrocene-based P,C,P pincer complexes 3a and $\mathbf{3 b}$ and to compare their geometric features with those of known benzene-based analogs and related pincer complexes of palladium. The X-ray structures of several benzene-based P,C,P pincer chloro palladium complexes have been described previously (Chart 2). These include complexes $\mathbf{6 a}^{\mathbf{1 5 a}}, \mathbf{6} \mathbf{b}^{\mathbf{1 5 b}}$, and $\mathbf{6 c}^{\mathbf{1 5 c}}$, complexes $\mathbf{7}^{\mathbf{1 5 d}}$ and $\mathbf{8}^{\mathbf{1 5 e}}$ containing chiral P,C,P ligands, complexes $9^{\mathbf{1 6 a}}$ and $\mathbf{1 0}^{\mathbf{1 6 b}}$ based on 1,5-bis(di-tert-butylphosphino)pentane and 1,8-bis(diphenylphosphino)anthracene pincer ligands, and phosphinito P,C,P pincer complex 11 $11^{16 c}$. The structures of cationic complexes containing two-electron donor ligands at the $\mathrm{Pd}$ atom, $\left[\mathrm{Pd}\left(\mathrm{OH}_{2}\right)\{2,6-\right.$ $\left.\left.\mathrm{Ph}_{2} \mathrm{PCH}_{2}\right)_{2} \mathrm{C}_{6} \mathrm{H}_{3}\right\} \mathrm{BF}_{4} \quad$ (two crystallographic isomers) ${ }^{15 a}$ $\left[\mathrm{Pd}\left(\mathrm{OH}_{2}\right)\left\{\left(\mathrm{Bu}_{2}{ }_{2} \mathrm{PCH}_{2} \mathrm{CH}_{2}\right)_{2} \mathrm{CH}\right\}\right] \mathrm{BPh}_{4}{ }^{\mathbf{1 6 a}} \quad(\mathbf{1 3}), \quad\left[\mathrm{Pd}\left(\mathrm{NH}_{2} \mathrm{Ph}\right)\left\{2,6-\left(\mathrm{Ph}_{2} \mathrm{PCH}_{2}\right)_{2} \mathrm{C}_{6} \mathrm{H}_{3}\right\}\right] \mathrm{BF}_{4}{ }^{17 \mathbf{a}}$ (14), and $\left[\mathrm{Pd}\left(\mathrm{PEt}_{3}\right)\left\{2,6-\left(\mathrm{Ph}_{2} \mathrm{PCH}_{2}\right)_{2} \mathrm{C}_{6} \mathrm{H}_{3}\right\}\right] \mathrm{BF}_{4}{ }^{\mathbf{1 7 b}}(\mathbf{1 5})$, have also been determined.

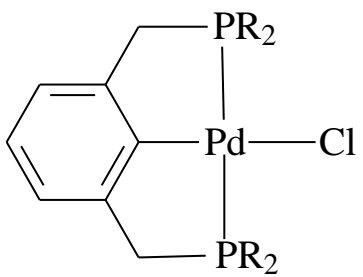

6a, $\mathrm{R}=\mathrm{Bu}^{\mathrm{t}}$

6b, $\mathrm{R}=\mathrm{Cy}$

6c, $\mathrm{R}=\mathrm{Ph}$

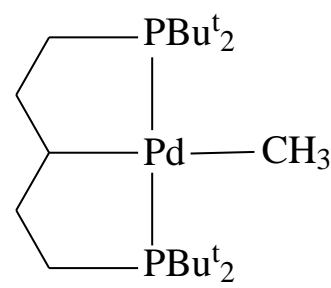

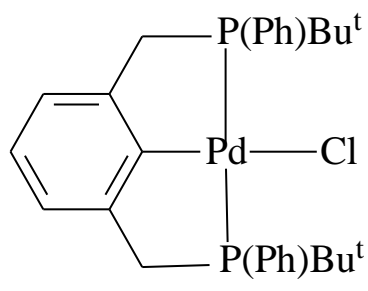

7

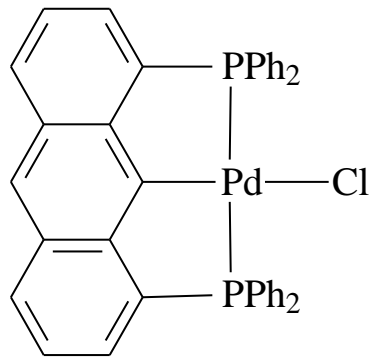

10

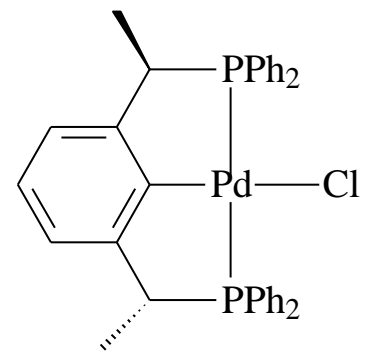

8

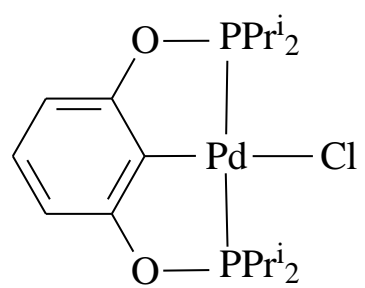

11

Chart 2 
The molecular structures of $\mathbf{3 a}$ and $\mathbf{3 b}$ are illustrated in Figures 1 and 2, respectively, while the selected bond distances and angles are listed in Tables 1. As may be seen from Figures 1 and 2, the structures of both molecules are very similar and contain the Pd atom in a distorted square-planar geometry, with $\mathrm{P}(1)-\mathrm{Pd}-\mathrm{P}(2)$ angles in $\mathbf{3 a}$ and $\mathbf{3 b}$ being equal to 160.39(6) and $157.57(4)^{\circ}$, respectively. These values are markedly smaller than the corresponding angles in benzene-based pincer complexes 6-10, where they are in the 162.0(1) - 166.2(1) ${ }^{\circ}$ range. They are also smaller relative to the two forms of complex 12, 166.26(8) and $167.6(1)^{\circ}$, and similar to those in the cationic complexes $\mathbf{1 4}$ and $\mathbf{1 5}, 160.8(3)$ and 158.1(1) ${ }^{\circ}$, respectively. (In 9, 10, 11, and $13 \mathrm{P}(1)-\mathrm{Pd}-\mathrm{P}(2)$ angles are 166.2(1), 166,2(1), 160.380(6), and 157.770(7) (for two independent molecules), and 167.1(1), respectively).

As well as in the case of rhodium complex $\mathbf{1}$, the formation of palladium complexes 3a and $\mathbf{3 b}$ leads to a decrease in the bond angles at $\mathrm{C}(2)$ and $\mathrm{C}(5)$ in the fused metallacycles, which are (average means) 120.1(5) and $119.5(4)^{\circ}$, respectively. In complexes $\mathbf{3 a}$ and $\mathbf{3 b}$ the Pd atom deviates from the plane of the cyclopentadienyl ring and lies 0.147 and $0.069 \AA$ above the ring in $\mathbf{3 a}$ and $\mathbf{3 b}$, respectively.

The distinguishing features of $\mathbf{3 a}$ and $\mathbf{3 b}$ in comparison with benzene systems are also an increase of the Pd-P bond distances and a flattening of the two fused metallacycles. Thus, the Pd-P distance [average 2.3391(12) $\AA$ ] in $\mathbf{3 b}$ is markedly longer than in its benzene analog 6a, 2.3025(6) $\AA$. In benzene-based P,C,P pincer complexes the two chelate five membered metallacycles are strained and adopt an envelope conformation with the methylene carbon at the flap. As a result, the plane of the aromatic ring is tilted from the coordination plane. Thus, in 6c, for example, the coordination plane defined by $\mathrm{Pd}, \mathrm{Cl}, \mathrm{C}(1), \mathrm{P}(1)$, and $\mathrm{P}(2)$ forms an angle of $19.85(5)^{\circ}$ with the cyclometalated benzene ring, and the $\mathrm{P}(1)$ and $\mathrm{P}(2)$ atoms are situated at the opposite sides of the benzene plane ${ }^{15 c}$. As a consequence, at each side of the benzene ring of $\mathbf{6 c}$ one of the phenyl groups at the $\mathrm{P}$ atom is pseudoaxial, and the other is 
pseudoequatorial. In contrast to $\mathbf{6 c}$ and other benzene-based P,C,P pincer complexes, the two pseudoaxial groups in metallocene-based pincer complexes $\mathbf{3 a}$ and $\mathbf{3 b}$ are located at the opposite sides of the cyclometalated cyclopentadienyl ring with respect to the two pseudoequatorial groups, see Figure 3. The phosphorus atoms $\mathrm{P}(1)$ and $\mathrm{P}(2)$ are located on the same side of the plane containing the substituted cyclopentadienyl ring, opposite to the iron atom. This deviation is probably due to a close contact between the hydrogen atoms of the methyl groups in the $\mathrm{P}(1)$ and $\mathrm{P}(2)$ substituents and the hydrogen atoms of the unsubstituted cyclopentadienyl ring. Thus, the chelated metal atom $\mathrm{M}$ is more shielded against the attack from the exo position in the metallocene-based pincer complexes than in the benzene-based complexes. Evidently, this peculiarity should be kept in mind for the design of metallocenebased P,C,P pincer complexes as catalysts for various reactions.

There are some other structural features in complexes $\mathbf{3 a}$ and $\mathbf{3 b}$. Thus, the $\mathrm{Pd}-\mathrm{Cl}$ distances [2.4002(17) and 2.4030(11) A, respectively] are longer than for 6c (2.367(3) $\mathrm{A})$, and close to those for $\mathbf{6 a}(2.3969(6) \AA)$ and $\mathbf{6 b}(2.427(2) \AA)$, which contain bulky alkyl groups at the $\mathrm{P}$ atoms ${ }^{15 a, b}$. It can not be ruled out that weakening of the $\mathrm{Pd}-\mathrm{Cl}$ bond in $\mathbf{3 a}$ and $\mathbf{3 b}$ is the result of steric congestion by the bulky isopropyl or tert-butyl groups. It should be noted in this respect that the angles $\mathrm{C}(1)-\mathrm{Pd}-\mathrm{Cl}$ in complexes $\mathbf{3 a}$ and $\mathbf{3 b}$ are $178.89(17)$ and $175.46(12)^{\circ}$, respectively, and this difference may also originate from steric congestion by the bulkier tertbutyl groups.

The molecular structure of complex $\mathbf{5 b}$ is illustrated in Figure 4; the main bond lengths and angles are presented in Table 2. The structural features of the pincer ligand of molecule 5b are similar to those of complex $\mathbf{3 b}$; in both complexes the cyclopentadienyl rings are deviated from being parallel by 4.2 and $4.5^{\circ}$, respectively, and have the eclipsed conformation. The coordination geometry of Pd in $\mathbf{5 b}$ is essentially square planar with slight distortion towards tetrahedral, with a $\mathrm{P}(1)-\mathrm{Pd}-\mathrm{P}(2)$ angle of $160.72(3)^{\circ}$. The palladium atom 
coordinates only one of the $\mathrm{BH}_{4}{ }^{-}$group hydrogen atoms, with the $\mathrm{Pd}-\mathrm{H}(1)$ distance of 2.00(4) A. As well as in other metallocene-based P,C,P pincer complexes, the chelated metal atom in 5b deviates from the plane of the cyclopentadienyl ring, the Pd atom lies $0.361 \AA$ above the ring. Three atoms, $\mathrm{C}(1), \mathrm{Pd}$, and $\mathrm{B}$ form an angle of $173.6(3)^{\circ}$, and the $\mathrm{Pd}-\mathrm{H}(1)-\mathrm{B}$ angle is $123.3^{\circ}$. It should be mentioned that in transition metal complexes with the unidentate $\mathrm{BH}_{4}{ }^{-}$ ligand, $\mathrm{M}-\mathrm{H}_{\mathrm{b}}-\mathrm{B}$ angles vary in a broad range. Thus, in $\mathrm{FeH}\left(\eta^{1}-\mathrm{BH}_{4}\right)(\mathrm{dmpe})_{2}{ }^{\mathbf{1 8 a}, \mathbf{b}}$ and trans$\operatorname{RuH}\left(\eta^{1}-\mathrm{BH}_{4}\right)\left(\mathrm{Me}_{8}[16] \mathrm{aneS}_{4}\right)^{\mathbf{1 9}}$ the $\mathrm{M}-\mathrm{H}_{\mathrm{b}}-\mathrm{B}$ angles are 161.7 and $164(1)^{\circ}$, respectively, while in $\mathrm{Cu}\left(\eta^{1}-\mathrm{BH}_{4}\right)\left(\mathrm{PMePh}_{2}\right)_{3}{ }^{20 \mathrm{a}}$ and $\mathrm{Cu}\left(\eta^{1}-\mathrm{BH}_{4}\right)(\text { triphos })^{\mathbf{2 1}}$ those angles are substantially smaller, 121.7(4) and $121(3)^{\circ}$, respectively. Intermediate $\mathrm{M}-\mathrm{H}_{\mathrm{b}}-\mathrm{B}$ angles were observed for complexes $\mathrm{Ag}\left(\eta^{1}-\mathrm{BH}_{4}\right)\left(\mathrm{PMePh}_{2}\right)_{3}{ }^{\mathbf{2 3}}$ and $\mathrm{V}\left(\eta^{1}-\mathrm{BH}_{4}\right)_{2}(\mathrm{dmpe})_{2}{ }^{\mathbf{2 2}}$, while the isostructural complexes $\mathrm{M}\left(\eta^{1}-\right.$ $\left.\mathrm{BH}_{4}\right)(\mathrm{CO})(\mathrm{NO})\left(\mathrm{PMe}_{3}\right)_{3}(\mathrm{M}=\mathrm{Mo}, \mathrm{W})^{24}$ contain two independent molecules, in which the M$\mathrm{H}_{\mathrm{b}}-\mathrm{B}$ angles are $128.5,142.4$, and $138.5,146.6^{\circ}$, respectively.

The Pd $\cdots \mathrm{B}$ distance of $2.614(7) \AA$ is too long to suppose Pd-B bonding in complex 5b. For comparison, in complex $\operatorname{Ti}\left(\mathrm{BH}_{4}\right)_{3}\left(\mathrm{PMe}_{3}\right)_{2}{ }^{25}$ containing unique "agostic" or "side-on" bonding of the Ti atom with two $\mathrm{BH}_{4}{ }^{-}$groups, the Ti-B distance is 2.27(1) $\AA$. A similar short M-B distance was also observed for complexes where the metal atom is bound to two hydrogen atoms of the $\mathrm{BH}_{4}{ }^{-}$group, for example $2.29 \AA$ in $\mathrm{Co}\left(\eta^{2}-\mathrm{BH}_{4}\right)(\text { triphos })^{\mathbf{2 6}}$. However, it may be noted that the Pd $\cdots B$ distance in $\mathbf{5 b}$ is markedly shorter in comparison to other $\eta^{1}$ $\mathrm{BH}_{4}$ derivatives of transition metals; for example 2.833(4), 2.84, and 2.895(16) $\AA$ in complexes $\quad \mathrm{V}\left(\eta^{1}-\mathrm{BH}_{4}\right)_{2}(\mathrm{dmpe})_{4}{ }^{\mathbf{2 3}}, \quad \mathrm{FeH}\left(\eta^{1}-\mathrm{BH}_{4}\right)(\mathrm{dmpe})_{2}{ }^{\mathbf{1 8}}, \quad$ and $\quad \mathrm{RuH}\left(\eta^{1}-\right.$ $\left.\mathrm{BH}_{4}\right)\left(\mathrm{Me}_{8}[16] \mathrm{aneS}_{4}\right)^{\mathbf{1 9}}$, respectively. This fact as well as the relatively short distance between the palladium atom and one of the three terminal hydrogen atoms of the $\mathrm{BH}_{4}{ }^{-}$group, $\mathrm{Pd} \cdots$ $\mathrm{H}(2)$ 2.56(5) $\AA$, allows us to describe the latter contact as an "incipient Pd-H bonding interaction" like it was proposed for complex $\mathrm{Cu}\left(\eta^{1}-\mathrm{BH}_{4}\right)\left(\mathrm{PMePh}_{2}\right)_{3}{ }^{20 a}$. In the related complex $\mathrm{Hf}_{2} \mathrm{H}_{3}\left(\mathrm{BH}_{4}\right)_{3}\left[\mathrm{~N}\left(\mathrm{SiMe}_{2} \mathrm{CH}_{2} \mathrm{PMe}_{2}\right)_{2}\right]_{2}$, the bonding of one of the $\mathrm{BH}_{4}{ }^{-}$groups is 
intermediate between the $\eta^{1}$ - and $\eta^{2}$-modes (the Hf-H distances are 1.93 and $\left.2.43 \AA\right)^{\mathbf{2 0 b}}$. Evidently, equilibration of the hydrogen atoms of the $\mathrm{BH}_{4}{ }^{-}$group in solution of $\mathbf{5 b}$ should include stepwise formation of $\eta^{1}$ - and $\eta^{2}$ - structures accompanied by rotation of the unidentate $\mathrm{BH}_{4}^{-}$group.

It is known that the $\mathrm{BH}_{4}{ }^{-}$ion and electronically neutral boran-Lewis base adducts $\mathrm{BH}_{3} \cdot \mathrm{L}$ are isoelectronic with alkanes and form relatively stable complexes with transition metals. ${ }^{\mathbf{1 4 a}, 27}$ At the same time, the alkane $\sigma$-complexes of transition metals are extremely unstable, and only recently have become available for observation under specific conditions ${ }^{\mathbf{2 8}}$. Shimoi and coworkers showed that properties of metal complexes with unidentate boraneLewis base adducts embodied those of alkane complexes. ${ }^{27}$

Several modes of metal-alkane interactions were suggested for alkane $\sigma$-complexes (Chart 3), intermediates in alkane oxidative addition reactions. Although alkane activation was not observed for $\mathrm{Pd}(\mathrm{II})$ in pincer complexes, it is reasonable to regard the interaction of the chelated, sterical crowded $\mathrm{Pd}$ atom with $\mathrm{BH}_{4}{ }^{-}$in $\mathbf{5 b}$ as modeling an earlier stage of alkane oxidative addition to the $\operatorname{Ir}$ atom in $\operatorname{Ir}\left[{ }^{\mathrm{R}} \mathrm{P}, \mathrm{C}, \mathrm{P}^{\mathrm{M}}\right]$, catalytic species for alkane dehydrogenation. Remarkably, the distances between the $\mathrm{Pd}$ atom and two hydrogen atoms of the $\mathrm{BH}_{4}{ }^{-}$group in 5b $(\mathrm{Pd}-\mathrm{H}(1)=2.00(4) \AA$ and $\mathrm{Pd}-\mathrm{H}(2)=2.56(5) \AA)$ and corresponding $\mathrm{Ir}-\mathrm{H}$ bond distances of 2.017 and $2.554 \AA$, calculated for the hypothetical intermediate agostic complex of ethane with $\operatorname{Ir}\left[2,6-\left(\mathrm{H}_{2} \mathrm{PCH}_{2}\right)_{2} \mathrm{C}_{6} \mathrm{H}_{3}\right]$, are very similar. ${ }^{27 c}$<smiles>CCCCCC</smiles>

$\eta-\mathrm{H}$ end-on<smiles>[M]C1CC1</smiles>

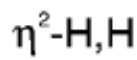<smiles>CCC(C)C</smiles>

$\eta^{2}-\mathrm{H}, \mathrm{C}$ side-on

Chart 3 


\section{Electrochemical Studies of $2 \mathrm{~b}, 3 \mathrm{a}$ and $3 \mathrm{~b}$}

As mentioned above, one of the peculiarities of the ferrocene-based pincer complexes is their potential to undergo a rapid and reversible redox process centered on the iron atom. We suppose that upon altering the redox state of the iron atom in ferrocene-based pincer complexes we can modify the chemical and catalytic reactivity of the chelated metal atom M, situated at the $\beta$-position to the iron atom. There is some resemblance with $\alpha$ ferrocenylcarbenium ions, the enhanced stability of which results from the direct interaction between the iron atom and the carbenium ion center, also situated at the $\beta$-position to iron. Therefore, by altering the iron oxidation state within the pincer ligand, we can enhance the rate of either oxidative addition or reductive elimination at $\mathrm{M}$. Thus, it is known that an increase in the electron density at the metal favors oxidative addition, whereas oxidation of metal complexes containing $\sigma$-bonded ligands leads to enhanced tendency toward reductive elimination by the loss of $\sigma$-bonded ligands ${ }^{29}$.

The redox properties of the ligand $\mathbf{2} \mathbf{b}$ and the complexes $\mathbf{3 a}$ and $\mathbf{3 b}$ were investigated by cyclic voltammetry. The results, see Figure 5, demonstrate that ligand and both complexes display reversible oxidation processes. All waves have a $\Delta \mathrm{E}_{\mathrm{p}}$ equal or smaller than that measured for an internal ferrocene standard, in agreement with their nature as one-electron redox processes. The free ligand $\mathbf{2} \mathbf{b}$ is oxidized at $\mathrm{E}_{1 / 2}=-0.11 \mathrm{~V} v$ s. ferrocene, i.e. their oxidation is slightly more facile than that of ferrocene, in line with the expected electron donating effect of the two $\mathrm{CH}_{2} \mathrm{PR}_{2}$ arms on the cyclopentadienyl ring. The palladium complexes 3a and $\mathbf{3 b}$ show oxidation potentials very close to each other $\left(E_{1 / 2}=-0.21\right.$ and $-0.22 \mathrm{~V}$ vs. ferrocene, respectively), slightly more negative than the corresponding free ligands. The small shift with respect to the free ligand suggests that the processes are once again Fe-based. Besides, square planar Pd(II) complexes do not show reversible electrochemistry at potentials close to ferrocene. ${ }^{\mathbf{3 0}}$ The observation that the redox potentials 
shift to more negative values relative to the free ligand is interesting. It means that the global effect of phosphorus coordination and metallation makes the Fe center electron richer. The donation from the $\mathrm{P}$ donors to the $\mathrm{Pd}$ center decreases the electron density at the $\mathrm{P}$ atoms and the transmission of this electronic change to the ferrocene moiety through the $\mathrm{CH}_{2} \mathrm{PR}_{2}$ should make the ferrocene less electron rich. This means that the replacement of a cyclopentadienyl $\mathrm{C}-\mathrm{H}$ bond by a C-Pd bond more than compensates for this effect, transmitting more electron density to the Fe center.

\section{Conclusions}

We have presented here for the first time the synthesis, structure, and electrochemical properties of palladium ferrocene-based P,C,P pincer complexes, obtained by cyclometalation of 1,3-bis-dialkylphosphinomethylferrocenes. These include tetrahydroborato derivatives, the first palladium complexes containing a unidentate $\mathrm{BH}_{4}{ }^{-}$ligand. The X-ray diffraction study of chloro-palladium pincer complexes $\mathbf{3 a}$ and $\mathbf{3 b}$ reveals some interesting structural features, which distinguish them from their benzene analogs. These features should be kept in mind while designing metallocene-based P,C,P pincer complexes as catalysts for various reactions. The structural peculiarity of the $\mathrm{BH}_{4}{ }^{-}$ion bonding with palladium atom in $\mathbf{5 b}$ can be considered as modeling an early step of alkane oxidative addition to the metal center in $\operatorname{Ir}\left[{ }^{\mathrm{R}} \mathrm{P}, \mathrm{C}, \mathrm{P}^{\mathrm{M}}\right]$, catalytic species for alkane hydrogenation.

Unexpected effects of the cyclometalation process on the Fe-based redox properties have been observed for the pincer complexes $\mathbf{3 a}$ and $\mathbf{3 b}$. At the moment, we are extending our work by probing the effect of the iron oxidation state on the reactivity and catalytic properties of the chelated metal atom in ferrocene-based pincer complexes. 


\section{Experimental Section}

All manipulations were carried out under an argon atmosphere. The ${ }^{1} \mathrm{H},{ }^{11} \mathrm{~B},{ }^{13} \mathrm{C}$, and

${ }^{31} \mathrm{P}$ NMR spectra were recorded on a Bruker AMX-400 spectrometer. FTIR spectra were recorded on a Nicolet Magna 750 spectrophotometer, and mass-spectra were measured on a Finnigan LCQ instrument. Cyclic voltammograms were recorded with an EG\&G 362 potentiostat connected to a Macintosh computer through MacLab hardware/sofware. The electrochemical cell was fitted with an $\mathrm{Ag}-\mathrm{AgCl}$ reference electrode, a $1 \mathrm{~mm}$ diameter $\mathrm{Pd}$ disk working electrode and a platinum wire counter-electrode. $\left[\mathrm{Bu}_{4} \mathrm{~N}\right] \mathrm{PF}_{6}(\mathrm{ca} .0 .1 \mathrm{M})$ was used as supporting electrolyte in THF. All potentials are reported relative to the ferrocene/ferricenium couple. Ferrocene was added and measured as an internal standard at the end of each experiment. Compound 1-(ethoxycarbonyl)-3-(formyl)ferrocene was prepared as described in the literature ${ }^{31}$.

Synthesis of $\left\{1,3-\left(\mathrm{HOCH}_{2}\right)_{2} \mathrm{C}_{5} \mathrm{H}_{3}\right\} \mathrm{Fe}\left(\mathrm{C}_{5} \mathrm{H}_{5}\right)$. A solution of 1-(ethoxycarbonyl)-3(formyl)ferrocene $(150 \mathrm{mg}, 0.524 \mathrm{mmol})$ in ether $(30 \mathrm{ml})$ was added dropwise to a suspension of $\mathrm{LiAlH}_{4}(60 \mathrm{mg}, 15.7 \mathrm{mmol})$ in ether $(30 \mathrm{ml})$. The solution was stirred at room temperature for $4.5 \mathrm{~h}$. Then water $(50 \mathrm{ml})$ was added and the water layer was separated and extracted with dichloromethane. The combined organic layers were dried over $\mathrm{Na}_{2} \mathrm{SO}_{4}$. The solvents were evaporated under vacuum, and the resulting yellow oil was purified on an alumina column (eluent methanol). Recrystallization of the residue from methanol gave orange-yellow crystals of the product. Yield: $100 \mathrm{mg}(77.5 \%)$. Mp: $115-116{ }^{\circ} \mathrm{C}$; lit. ${ }^{32} \mathrm{mp} 115-116{ }^{\circ} \mathrm{C} .{ }^{1} \mathrm{H}$ NMR (acetone- $\left.d_{6}\right): \delta 4.11\left(\mathrm{~s}, 5 \mathrm{H}, \mathrm{C}_{5} \mathrm{H}_{5}\right), 4.13\left(\mathrm{~d}, 2 \mathrm{H}, J=1.1 \mathrm{~Hz}, \mathrm{HC}_{5} \mathrm{H}_{2}\right), 4.25(\mathrm{t}, 1 \mathrm{H}, J=1.1 \mathrm{~Hz}$, $\left.\mathrm{HC}_{5} \mathrm{H}_{2}\right), 4.29\left(\mathrm{~s}, 4 \mathrm{H}, \mathrm{CH}_{2} \mathrm{OH}\right)$.

Synthesis of $\left\{\mathbf{1 , 3}-\left(\operatorname{Pr}^{\mathrm{i}}{ }_{2} \mathbf{P C H}_{2}\right)_{2} \mathbf{C}_{5} \mathbf{H}_{3}\right\} \mathbf{F e}\left(\mathbf{C}_{5} \mathbf{H}_{5}\right)$ (2a). Phosphine $\operatorname{HPPr}_{2}{ }_{2}(602 \mathrm{mg}, 5.10$ mmol) was added to a solution of dicarbinol $\left\{1,3-\left(\mathrm{HOCH}_{2}\right)_{2} \mathrm{C}_{5} \mathrm{H}_{3}\right\} \mathrm{Fe}\left(\mathrm{C}_{5} \mathrm{H}_{5}\right)(502 \mathrm{mg}, 2.04$ 
mmol) in acetic acid $(40 \mathrm{ml})$. The solution was stirred at $95^{\circ} \mathrm{C}$ for $3 \mathrm{~h}$. The solvent was removed under vacuum, and the residue was extracted with dichloromethane $(60 \mathrm{ml})$. The extract was washed with a saturated aqueous $\mathrm{Na}_{2} \mathrm{CO}_{3}$ solution $(50 \mathrm{ml})$. The layers were separated, and the aqueous solution was extracted with $\mathrm{CH}_{2} \mathrm{Cl}_{2}(2 \times 50 \mathrm{ml})$. The combined organic solutions were evaporated and the residue was dissolved in anhydrous methanol. Crystallization at $-78^{\circ} \mathrm{C}$ gave light yellow crystals (yellow-brown oil at room temperature). Yield: $409 \mathrm{mg}(45 \%) .{ }^{31} \mathrm{P}\left\{{ }^{1} \mathrm{H}\right\} \mathrm{NMR}\left(\mathrm{CDCl}_{3}\right): \delta 9.14$ (s, 2P). ${ }^{1} \mathrm{H}$ NMR $\left(\mathrm{CDCl}_{3}\right): \delta$ 0.96-1.04 (m, 24H, $\left.\mathrm{CH}\left(\mathrm{CH}_{3}\right)_{2}\right), 1.6-1.7\left(\mathrm{~m}, 4 \mathrm{H}, \mathrm{CH}\left(\mathrm{CH}_{3}\right)_{2}\right), 2.48$ (br.s, $\left.4 \mathrm{H}, \mathrm{CH}_{2} \mathrm{P}\right), 4.01\left(\mathrm{~s}, 2 \mathrm{H}, \mathrm{C}_{5} \mathrm{H}_{2} \mathrm{H}\right)$, $4.02\left(\mathrm{~s}, 5 \mathrm{H}, \mathrm{C}_{5} \mathrm{H}_{5}\right), 4.13\left(\mathrm{~s}, 1 \mathrm{H}, \mathrm{C}_{5} \mathrm{H}_{2} \mathrm{H}\right)$.

Synthesis of $\left\{1,3-\left(\mathrm{Bu}_{2}{ }_{2} \mathrm{PCH}_{2}\right)_{2} \mathrm{C}_{5} \mathrm{H}_{3}\right\} \mathrm{Fe}\left(\mathrm{C}_{5} \mathrm{H}_{5}\right)$ (2b). The phosphination of 1,3bis(hydroxymethyl)ferrocene $(500 \mathrm{mg}, 2.03 \mathrm{mmol})$ with $\mathrm{HPBu}_{2}^{\mathrm{t}}(600 \mathrm{mg}, 4.10 \mathrm{mmol})$ was done according to the procedure described above for the synthesis of 2a. Precipitation of the product by addition of methanol to the concentrated solution in dichloromethane gave light yellow needles. Yield: $613 \mathrm{mg}(60 \%) .{ }^{31} \mathrm{P}\left\{{ }^{1} \mathrm{H}\right\} \mathrm{NMR}\left(\mathrm{CDCl}_{3}\right): \delta 34.46(\mathrm{~s}, 2 \mathrm{P}) .{ }^{1} \mathrm{H}$ NMR $\left(\mathrm{CDCl}_{3}\right): \delta 1.02-1.12\left(2 \mathrm{~d}, 36 \mathrm{H}, J=4.5 \mathrm{~Hz}, \mathrm{C}\left(\mathrm{CH}_{3}\right)_{3}\right), 2.53$ (br.s, 4H, $\left.\mathrm{CH}_{2} \mathrm{P}\right), 4.02$ (s, 5H, $\left.\mathrm{C}_{5} \mathrm{H}_{5}\right), 4.13\left(\mathrm{~s}, 2 \mathrm{H}, \mathrm{C}_{5} \mathrm{H}_{2} \mathrm{H}\right), 4.31\left(\mathrm{~s}, 1 \mathrm{H}, \mathrm{C}_{5} \mathrm{H}_{2} \mathrm{H}\right) . \mathrm{MS}: 502\left[\mathrm{M}^{+}\right]$.

Synthesis of $\mathrm{PdCl}\left[\left\{2,5-\left(\mathrm{Pr}_{2}{ }_{2} \mathrm{PCH}_{2}\right)_{2} \mathrm{C}_{5} \mathrm{H}_{2}\right\} \mathrm{Fe}\left(\mathrm{C}_{5} \mathrm{H}_{5}\right)\right](3 \mathrm{a}) . \mathrm{PdCl}_{2}\left(\mathrm{NCPh}_{2}(440 \mathrm{mg}\right.$, $1.154 \mathrm{mmol}$ ) was added to the suspension of 1,3-bis(diisopropylphosphinomethyl)ferrocene (2a) $(515 \mathrm{mg}, 1.154 \mathrm{mmol})$ in dry 2 -methoxyethanol $(50 \mathrm{ml})$. The mixture was stirred at $125^{\circ}$ $\mathrm{C}$ for $3 \mathrm{~h}$. After cooling, the orange solution was filtered and solvent was removed under vacuum. The residue was crystallized from a $n$-hexane- $\mathrm{CH}_{2} \mathrm{Cl}_{2}$ mixture. Yield: $320 \mathrm{mg}(47 \%)$. ${ }^{31} \mathrm{P}\left\{{ }^{1} \mathrm{H}\right\}$ NMR $\left(\mathrm{CDCl}_{3}\right): \delta 71.87(\mathrm{~s}, 2 \mathrm{P}) .{ }^{1} \mathrm{H}$ NMR $\left(\mathrm{CDCl}_{3}\right): \delta 1.07(\mathrm{vq}, J=7.8 \mathrm{~Hz}, 6 \mathrm{H}$, $\left.\mathrm{CH}\left(\mathrm{CH}_{3}\right)_{2}\right), 1.33$ (vq, J=7.4 Hz, 12H, $\left.\mathrm{CH}\left(\mathrm{CH}_{3}\right)_{2}\right), 1.53$ (vq, J=8.1 Hz, 6H, $\left.\mathrm{CH}\left(\mathrm{CH}_{3}\right)_{2}\right), 2.18$ $\left(\mathrm{m}, 2 \mathrm{H}, \mathrm{CH}\left(\mathrm{CH}_{3}\right)_{2}\right), 2.29\left(\mathrm{~m}, 2 \mathrm{H}, \mathrm{CH}_{\mathrm{A}} \mathrm{H}_{\mathrm{B}} \mathrm{P}\right), 2.53\left(\mathrm{~m}, 2 \mathrm{H}, \mathrm{CH}\left(\mathrm{CH}_{3}\right)_{2}\right), 2.76(\mathrm{~m}, 2 \mathrm{H}$, $\left.\mathrm{CH}_{\mathrm{A}} \mathrm{CH}_{B} \mathrm{P}\right), 4.01\left(\mathrm{~s}, 5 \mathrm{H}, \mathrm{C}_{5} \mathrm{H}_{5}\right), 4.23\left(\mathrm{~s}, 2 \mathrm{H}, \mathrm{C}_{5} \mathrm{H}_{2}\right) . \mathrm{MS}: 588\left[\mathrm{M}^{+}\right]$. 
Synthesis of $\mathrm{PdCl}\left[\left\{2,5-\left(\mathrm{Bu}_{2} \mathrm{PCH}_{2}\right)_{2} \mathrm{C}_{5} \mathrm{H}_{2}\right\} \mathrm{Fe}\left(\mathrm{C}_{5} \mathrm{H}_{5}\right)\right]$ (3b). This compound was obtained by the procedure described above for 3a. Yield: $65.2 \% .{ }^{31} \mathrm{P}\left\{{ }^{1} \mathrm{H}\right\} \mathrm{NMR}\left(\mathrm{CDCl}_{3}\right): \delta$ 85.78 (s, 2P). ${ }^{1} \mathrm{H}$ NMR $\left(\mathrm{CDCl}_{3}\right): \delta 1.27$ (vt, $\left.J=6.5 \mathrm{~Hz}, 18 \mathrm{H}, \mathrm{CH}_{3}\right), 1.55$ (vt, $J=7.0 \mathrm{~Hz}, 18 \mathrm{H}$, $\left.\mathrm{CH}_{3}\right), 2.48\left(\mathrm{dt}, J_{\mathrm{HH}}=16.5 \mathrm{~Hz}, J_{\mathrm{PH}}=2.0 \mathrm{~Hz}, 2 \mathrm{H}, \mathrm{CH}_{\mathrm{A}} \mathrm{CH}_{\mathrm{B}} \mathrm{P}\right), 2.90\left(\mathrm{dt}, J_{\mathrm{HH}}=16.5 \mathrm{~Hz}, J_{\mathrm{PH}}=1.1 \mathrm{~Hz}\right.$, 2H, $\left.\mathrm{CH}_{\mathrm{A}} \mathrm{CH}_{\mathrm{B}} \mathrm{P}\right), 3.94$ (s, 5H, $\left.\mathrm{C}_{5} \mathrm{H}_{5}\right), 4.23\left(\mathrm{~s}, 2 \mathrm{H}, \mathrm{C}_{5} \mathrm{H}_{2}\right) .{ }^{13} \mathrm{C}\left\{{ }^{1} \mathrm{H}\right\} \mathrm{NMR}\left(\mathrm{CDCl}_{3}\right): \delta 24.99$ (v.t, $J_{\mathrm{PC}}=10.3 \mathrm{~Hz}, 2 \mathrm{C}, \mathrm{CH}_{2} \mathrm{P}$ ), 29.33 ("tt", 6C, $\mathrm{CH}_{3}$ ), 29.41 (“t”, 6C, $\mathrm{CH}_{3}$ ), 35.06 (v.t, $J_{\mathrm{PC}}=6.7 \mathrm{~Hz}$, 2C, $C \mathrm{Me}_{3}$ ), 35.37 (vt, $\left.J_{\mathrm{PC}}=5.4 \mathrm{~Hz}, C \mathrm{Me}_{3}, 2 \mathrm{C}\right), 63.76\left(\mathrm{vt}, J_{\mathrm{PC}}=8.1 \mathrm{~Hz}, 2 \mathrm{C}, \mathrm{C}(3,4)\right), 70.62$ (s,

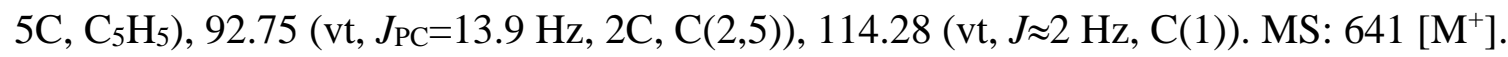

Synthesis of $\left\{\mathbf{P d C l}\left[\left\{2,5-\left(\mathrm{Bu}_{2}^{\mathrm{t}} \mathbf{P C H}_{2}\right)_{2} \mathrm{C}_{5} \mathrm{H}_{2}\right\} \mathbf{F e}\left(\mathbf{C}_{5} \mathbf{H}_{5}\right)\right]\right\} \mathbf{P F}_{6}(\mathbf{4 b}) \cdot\left[\mathrm{Cp}_{2} \mathrm{Fe}_{\mathrm{P}}\right] \mathrm{PF}_{6}$ (87.1 $\mathrm{mg}, 0.263 \mathrm{mmol})$ was added to a stirring solution of $\mathrm{PdCl}\left[\left\{2,5-\left(\mathrm{Bu}_{2}^{\mathrm{t}} \mathrm{PCH}_{2}\right)_{2} \mathrm{C}_{5} \mathrm{H}_{2}\right\} \mathrm{Fe}\left(\mathrm{C}_{5} \mathrm{H}_{5}\right)\right]$ (3b) (169 mg, $0.263 \mathrm{mmol})$ in dichloromethane $(20 \mathrm{ml})$. The solution rapidly changed colour to green. After stirring for $1 \mathrm{~h}$, the solvent was removed under vacuum, and the residue was extracted with toluene $(6.10 \mathrm{ml})$ to remove ferrocene. The green residue was dried in vacuum. Yield ca. $80 \% .{ }^{31} \mathrm{P}\left\{{ }^{1} \mathrm{H}\right\} \operatorname{NMR}\left(\mathrm{CD}_{2} \mathrm{Cl}_{2}\right): \delta 93.9$ (s, 2P), -150.0 (sept., ${ }^{1} \mathrm{~J}_{\mathrm{P}, \mathrm{F}}=709.5$ $\left.\mathrm{Hz}, 1 \mathrm{P}, \mathrm{PF}_{6}\right) .{ }^{1} \mathrm{H}$ NMR $\left(\mathrm{CD}_{2} \mathrm{Cl}_{2}\right): \delta-115.50\left(\mathrm{br}, 2 \mathrm{H}, \mathrm{CH}_{\mathrm{A}} \mathrm{H}_{\mathrm{B}} \mathrm{P}\right),-25.87$ (br, $\left.2 \mathrm{H}, \mathrm{CH}_{\mathrm{A}} H_{\mathrm{B}} \mathrm{P}\right),-$ 10.24 (s, 18H, C( $\left.\left.\mathrm{CH}_{3}\right)_{3}\right), 7.03$ (s, 18H, C( $\left.\left(\mathrm{CH}_{3}\right)_{3}\right), 24.42$ (br, 5H, $\left.\mathrm{C}_{5} \mathrm{H}_{5}\right), 29.52$ (br, $\left.2 \mathrm{H}, \mathrm{C}_{5} \mathrm{H}_{2}\right)$.

Synthesis of $\mathrm{Pd}\left(\mathrm{BH}_{4}\right)\left[\left\{2,5-\left(\mathrm{Bu}_{2}{ }_{2} \mathrm{PCH}_{2}\right)_{2} \mathrm{C}_{5} \mathrm{H}_{2}\right\} \mathrm{Fe}\left(\mathrm{C}_{5} \mathrm{H}_{5}\right)\right]$ (5b). To a solution of $\operatorname{PdCl}\left[\left\{2,5-\left(\mathrm{Bu}_{2}^{\mathrm{t}} \mathrm{PCH}_{2}\right)_{2} \mathrm{C}_{5} \mathrm{H}_{2}\right\} \mathrm{Fe}\left(\mathrm{C}_{5} \mathrm{H}_{5}\right)\right](3 \mathbf{b})(96 \mathrm{mg}, 0.15 \mathrm{mmol})$ in $40 \mathrm{ml}$ of ethanol $\mathrm{NaBH}_{4}$ (350 mg) was added, and the mixture refluxed for $1 \mathrm{~h}$. After cooling the yellow-orange solution, additional $\mathrm{NaBH}_{4}(100 \mathrm{mg})$ was added and the solution refluxed another $1 \mathrm{~h}$. After cooling the solvent was decanted and the white residue was washed several times with ethanol. The combined ethanol solutions were evaporated to dryness under vacuum. The residue was extracted with dichloromethane, $n$-hexane was added, and the solution was concentrated to a small volume $(3-4 \mathrm{ml})$ and cooled to $-20^{\circ} \mathrm{C}$ for $2 \mathrm{~h}$. The almost colorless supernatant was removed by pipette, the solid was washed with hexane and dried under 
vacuum, to yield an orange crystalline powder. Yield: $68.2 \mathrm{mg}(73 \%) .{ }^{31} \mathrm{P}\left\{{ }^{1} \mathrm{H}\right\} \mathrm{NMR}$ $\left(\mathrm{CDCl}_{3}\right): \delta 91.39$ (s, 2P). ${ }^{1} \mathrm{H} \mathrm{NMR}\left(\mathrm{CDCl}_{3}\right): \delta-0.50$ (pseudo q, $\left.J_{\mathrm{BH}}=97, J_{\mathrm{BH}}=55 \mathrm{~Hz}, 4 \mathrm{H}, \mathrm{BH}_{4}\right)$, $1.23\left(\mathrm{t}, J_{\mathrm{HP}}=6.7 \mathrm{~Hz}, 18 \mathrm{H}, \mathrm{CH}_{3}\right), 1.53\left(\mathrm{t}, J_{\mathrm{HP}}=7.2 \mathrm{~Hz}, 18 \mathrm{H}, \mathrm{CH}_{3}\right), 2.53\left(\mathrm{dt}, J_{\mathrm{HH}}=17.0 \mathrm{~Hz}\right.$, $\left.J_{\mathrm{HP}}=4.5 \mathrm{~Hz}, 2 \mathrm{H}, \mathrm{CH}_{\mathrm{A}} \mathrm{H}_{\mathrm{B}} \mathrm{P}\right), 3.01\left(\mathrm{dt}, J_{\mathrm{HH}}=17.0 \mathrm{~Hz}, J_{\mathrm{HP}}\right.$ ca. $\left.1.2 \mathrm{~Hz}, 2 \mathrm{H}, \mathrm{CH}_{\mathrm{A}} H_{\mathrm{B}} \mathrm{P}\right), 3.95(\mathrm{~s}, 5 \mathrm{H}$, $\left.\mathrm{C}_{5} \mathrm{H}_{5}\right), 4.22\left(\mathrm{~s}, 2 \mathrm{H}, \mathrm{C}_{5} \mathrm{H}_{2}\right) .{ }^{11} \mathrm{~B}$ NMR $\left(\mathrm{CDCl}_{3}\right)$ : -37.28 (quint., $\left.J_{\mathrm{BH}}=83.1 \mathrm{~Hz}\right) . \mathrm{IR}(\mathrm{KBr})$ : 2380(sh), 2369(vs), 2369(s), 1064(s) $\mathrm{cm}^{-1}$. MS: $608\left(\mathrm{M}^{+}-\mathrm{BH}_{3}\right)$.

Synthesis of $\mathbf{P d}\left(\mathrm{BH}_{4}\right)\left[\left\{2,5-\left(\operatorname{Pr}_{2} \mathrm{PCH}_{2}\right)_{2} \mathrm{C}_{5} \mathrm{H}_{2}\right\} \mathrm{Fe}\left(\mathrm{C}_{5} \mathrm{H}_{5}\right)\right]$ (5a). This compound was obtained by the procedure described above for 5a starting from $128.6 \mathrm{mg}$ of $\mathbf{3 a}$ and $400 \mathrm{mg}$ of $\mathrm{NaBH}_{4}$ in $40 \mathrm{ml}$ of ethanol. Yield: $59.2 \mathrm{mg}, 45 \% .{ }^{31} \mathrm{P}\left\{{ }^{1} \mathrm{H}\right\} \mathrm{NMR}\left(\mathrm{C}_{6} \mathrm{D}_{6}\right): \delta 78.05(\mathrm{~s}, 2 \mathrm{P}) .{ }^{1} \mathrm{H}$ $\operatorname{NMR}\left(\mathrm{C}_{6} \mathrm{D}_{6}\right): \delta 0.27$ (pseudo q, $J_{\mathrm{BH}}=97, J_{\mathrm{BH}}=55 \mathrm{~Hz}$ ), 0.89 (vq., $J=7.6 \mathrm{~Hz}, 6 \mathrm{H}, \mathrm{CHCH}_{3}$ ), 1.00 (vq., J=6.4 Hz, 6H, $\mathrm{CHCH}_{3}$ ), 1.26 (vq., J=7.8 Hz, 6H, CHCH 3 ), 1.53 (vq., g, J=8.0 Hz, 6H, $\left.\mathrm{CHCH}_{3}\right), 1.73\left(\mathrm{~m}, 2 \mathrm{H}, \mathrm{CHCH}_{3}\right), 2.04\left(\mathrm{dt}, J_{\mathrm{HH}}=16.6 \mathrm{~Hz}, J_{\mathrm{HP}}=4.3 \mathrm{~Hz}, 2 \mathrm{H}, \mathrm{CH}_{\mathrm{A}} \mathrm{H}_{\mathrm{B}} \mathrm{P}\right), 2.49(\mathrm{~m}$, $\left.2 \mathrm{H}, \mathrm{CHCH}_{3}\right), 2.70\left(\right.$ d,t. $\left.J_{\mathrm{HH}}=16.6 \mathrm{~Hz}, J_{\mathrm{HP}} \sim 1.2 \mathrm{~Hz}, 2 \mathrm{H}, \mathrm{CH}_{\mathrm{A}} H_{\mathrm{B}} \mathrm{P}\right), 4.11\left(\mathrm{~s}, 5 \mathrm{H}, \mathrm{C}_{5} \mathrm{H}_{5}\right), 4.25$ (s, $\left.2 \mathrm{H}, \mathrm{C}_{5} \mathrm{H}_{2}\right) .{ }^{11} \mathrm{~B} \mathrm{NMR}\left(\mathrm{C}_{6} \mathrm{D}_{6}\right): \delta-37.65$ (quint, $J_{\mathrm{BH}}=81.3 \mathrm{~Hz}$ ).

X-Ray diffraction studies. X-ray quality crystals of $\mathbf{3 a}, \mathbf{3 b}$ and $\mathbf{5 b}$ were obtained by slow crystallization from $n$-hexane/ $\mathrm{CH}_{2} \mathrm{Cl}_{2}$ and $\mathrm{CH}_{2} \mathrm{Cl}_{2}$ /ethanol respectively. Details of the data collection and structure refinement are presented in Table 3. The data were corrected for Lorentz and polarization effects. The chosen crystals were small, well formed and essentially isometric, resulting in low absorption coefficients. Therefore, no absorption correction was considered necessary. All structures have been solved by direct methods and refined by the full-matrix least-squares procedure with anisotropic thermal factors for all non-hydrogen atoms. The $\mathrm{H}$ atoms of the $\mathrm{BH}_{4}$ group in $\mathbf{5 b}$ were located in difference syntheses and refined isotropically; the other $\mathrm{H}$ atoms in $\mathbf{5 b}$ as well as all $\mathrm{H}$ atoms in $\mathbf{3 a}$ and $\mathbf{3 b}$ were placed at calculated positions and included in the structure factor calculation in the riding motion 
approximation. The absolute structure for 3a was defined by the Flack parameter ${ }^{\mathbf{3 3}}$ refinement $(\mathrm{x}=0.00(4))$. The SHELXTL-97 program package ${ }^{\mathbf{3 4}}$ was used throughout the calculations.

Acknowledgements. We are grateful to Russian Foundation for Basic Research (0303-31138 and 03-03-32499), to PowerNova Technologies Corp., to INTAS (00-00179), and to the European Commission's RTN Programme (HPRN-CT-2002-00176), for support of this work. 


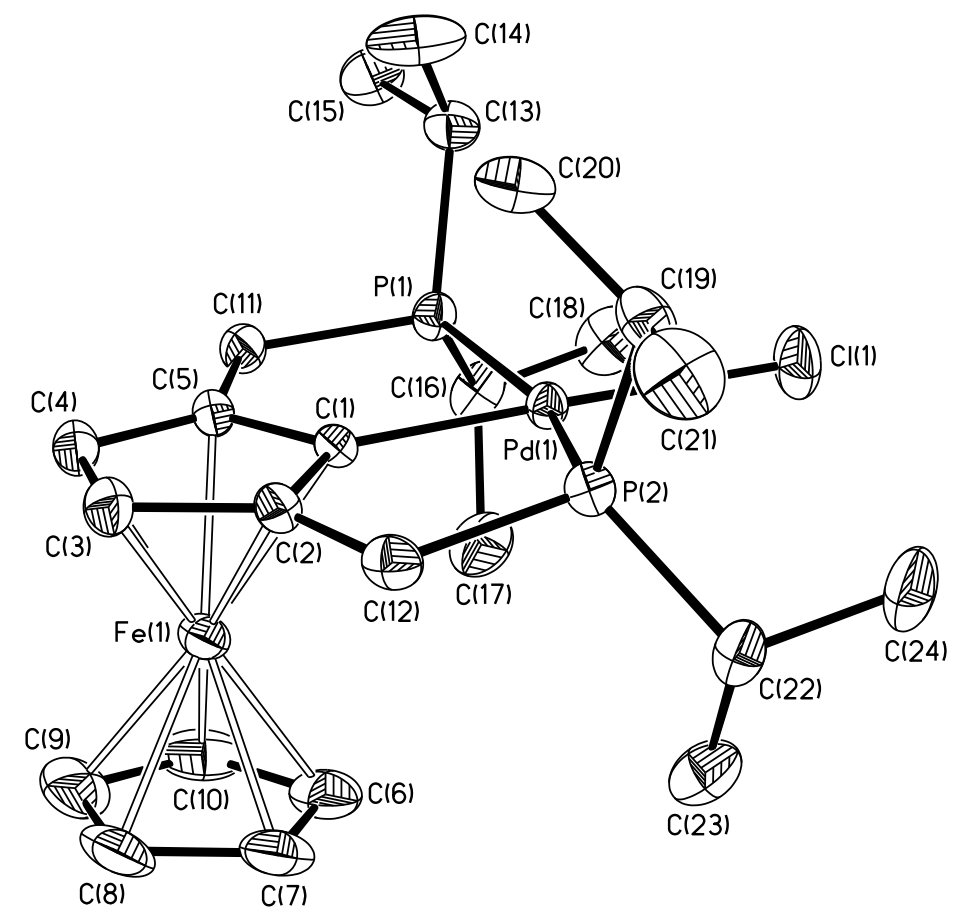

Figure 1. The molecular structure of $\mathbf{3 a}$. 


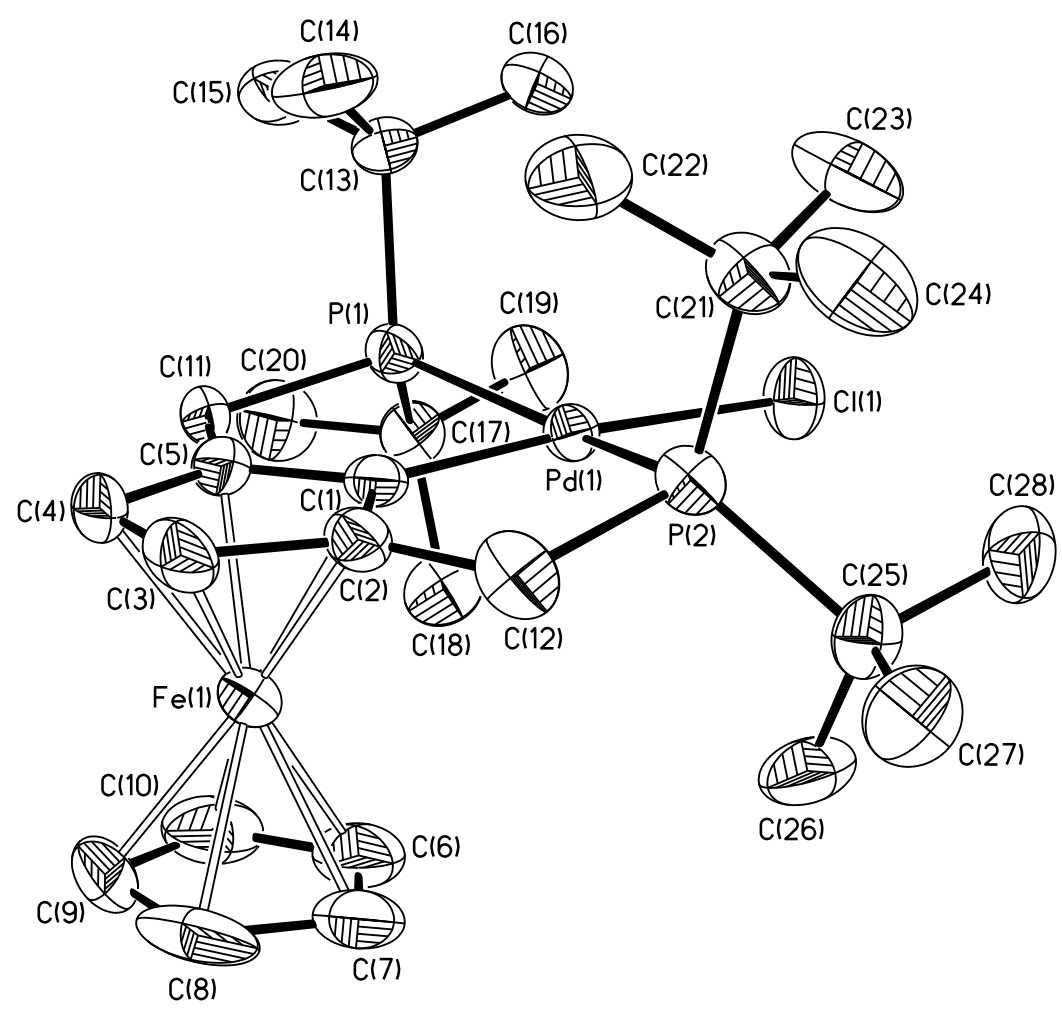

Figure 2. The molecular structure of $\mathbf{3 b}$. 
Table 1. Selected geometrical parameters for complexes $\mathbf{3 a}$ and $\mathbf{3 b}$.

\begin{tabular}{|c|c|c|c|c|c|}
\hline Bond $(\AA)$ & $3 \mathbf{a}$ & $3 \mathbf{b}$ & Angle $\left(^{\circ}\right)$ & $3 \mathbf{a}$ & $\mathbf{3 b}$ \\
\hline $\operatorname{Pd}(1)-\mathrm{Cl}(1)$ & $2.400(2)$ & $2.403(1)$ & $\mathrm{C}(1)-\mathrm{Pd}(1)-\mathrm{Cl}(1)$ & $179.0(2)$ & $175.5(1)$ \\
\hline $\operatorname{Pd}(1)-C(1)$ & $1.964(5)$ & $1.961(4)$ & $\mathrm{C}(1)-\mathrm{Pd}(1)-\mathrm{P}(1)$ & $80.9(2)$ & $80.8(1)$ \\
\hline $\operatorname{Pd}(1)-P(1)$ & $2.318(2)$ & $2.342(1)$ & $\mathrm{C}(1)-\mathrm{Pd}(1)-\mathrm{P}(2)$ & 81.1(2) & $80.7(1)$ \\
\hline $\operatorname{Pd}(1)-P(2)$ & $2.305(2)$ & $2.337(1)$ & $\mathrm{P}(1)-\mathrm{Pd}(1)-\mathrm{P}(2)$ & $160.39(6)$ & $157.57(4)$ \\
\hline$P(1)-C(11)$ & $1.842(6)$ & $1.857(4)$ & $\mathrm{P}(1)-\mathrm{Pd}(1)-\mathrm{Cl}(1)$ & $99.70(6)$ & $99.77(4)$ \\
\hline$P(2)-C(12)$ & $1.835(6)$ & $1.858(4)$ & $\mathrm{P}(2)-\mathrm{Pd}(1)-\mathrm{Cl}(1)$ & $98.48(6)$ & $99.65(4)$ \\
\hline $\mathrm{C}(1)-\mathrm{C}(2)$ & $1.433(7)$ & $1.420(6)$ & $\mathrm{C}(11)-\mathrm{P}(1)-\mathrm{Pd}(1)$ & $106.4(2)$ & $106.1(2)$ \\
\hline$C(1)-C(5)$ & $1.417(8)$ & $1.425(5)$ & $\mathrm{C}(12)-\mathrm{P}(2)-\mathrm{Pd}(1)$ & $106.7(2)$ & $104.7(2)$ \\
\hline$C(2)-C(3)$ & $1.436(8)$ & $1.421(5)$ & $C(2)-C(1)-C(5)$ & $108.6(5)$ & $107.5(4)$ \\
\hline$C(2)-C(12)$ & $1.494(8)$ & $1.502(6)$ & $\mathrm{C}(2)-\mathrm{C}(1)-\mathrm{Pd}(1)$ & $124.8(4)$ & $126.7(3)$ \\
\hline$C(3)-C(4)$ & $1.430(9)$ & $1.430(6)$ & $C(5)-C(1)-P d(1)$ & $126.4(4)$ & $125.7(3)$ \\
\hline$C(4)-C(5)$ & $1.416(8)$ & $1.414(6)$ & $C(1)-C(2)-C(3)$ & $107.0(5)$ & $108.2(4)$ \\
\hline \multirow[t]{9}{*}{$C(5)-C(11)$} & $1.513(8)$ & $1.525(6)$ & $\mathrm{C}(1)-\mathrm{C}(2)-\mathrm{C}(12)$ & $120.6(5)$ & 119.1(4) \\
\hline & & & $\mathrm{C}(3)-\mathrm{C}(2)-\mathrm{C}(12)$ & $132.5(5)$ & $132.7(4)$ \\
\hline & & & $C(2)-C(3)-C(4)$ & $108.0(5)$ & $108.1(4)$ \\
\hline & & & $C(5)-C(4)-C(3)$ & $108.2(5)$ & $107.4(4)$ \\
\hline & & & $C(4)-C(5)-C(1)$ & $108.3(5)$ & $108.8(4)$ \\
\hline & & & $C(4)-C(5)-C(11)$ & $132.0(5)$ & $130.2(4)$ \\
\hline & & & $C(1)-C(5)-C(11)$ & $119.6(5)$ & $121.0(4)$ \\
\hline & & & $\mathrm{C}(5)-\mathrm{C}(11)-\mathrm{P}(1)$ & $106.5(4)$ & $104.8(3)$ \\
\hline & & & $C(2)-C(12)-P(2)$ & $105.8(4)$ & $106.7(3)$ \\
\hline
\end{tabular}



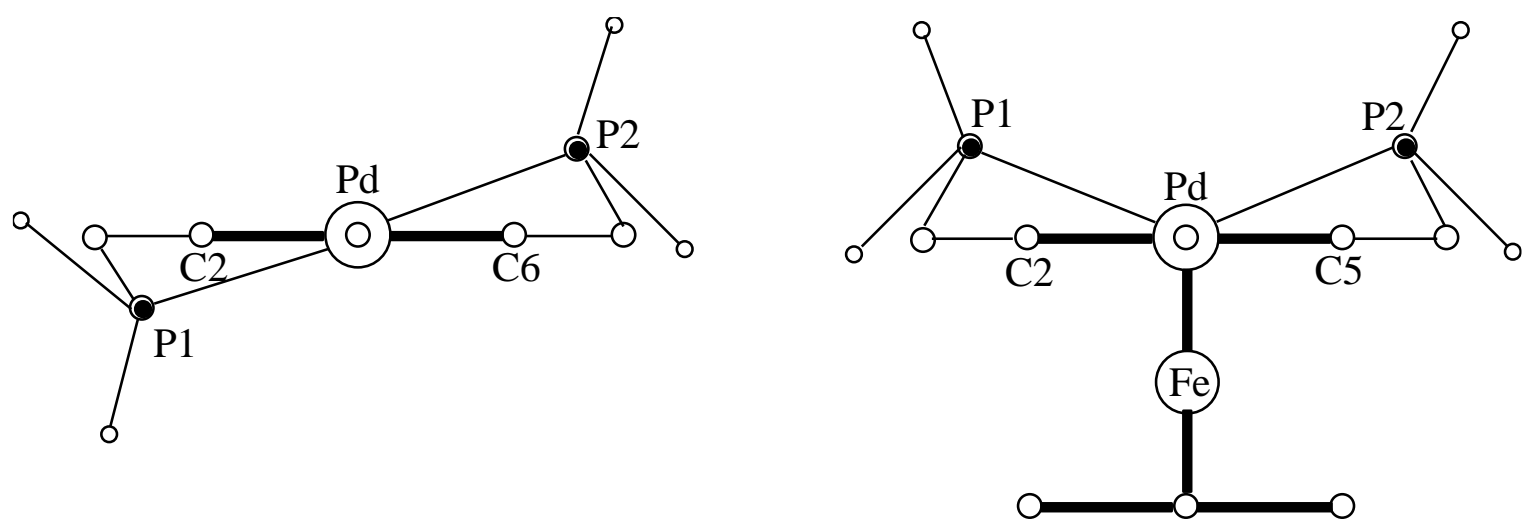

Figure 3. Projected views of P,C,P pincer complexes (left: benzene-based; right: ferrocenebased) along the $\mathrm{Cl}-\mathrm{Pd}-\mathrm{C}(1)$ axis. The $\mathrm{Cp}$ ring deviation from the $\mathrm{Pd}-\mathrm{Cl}$ axis is omitted for clarity. 


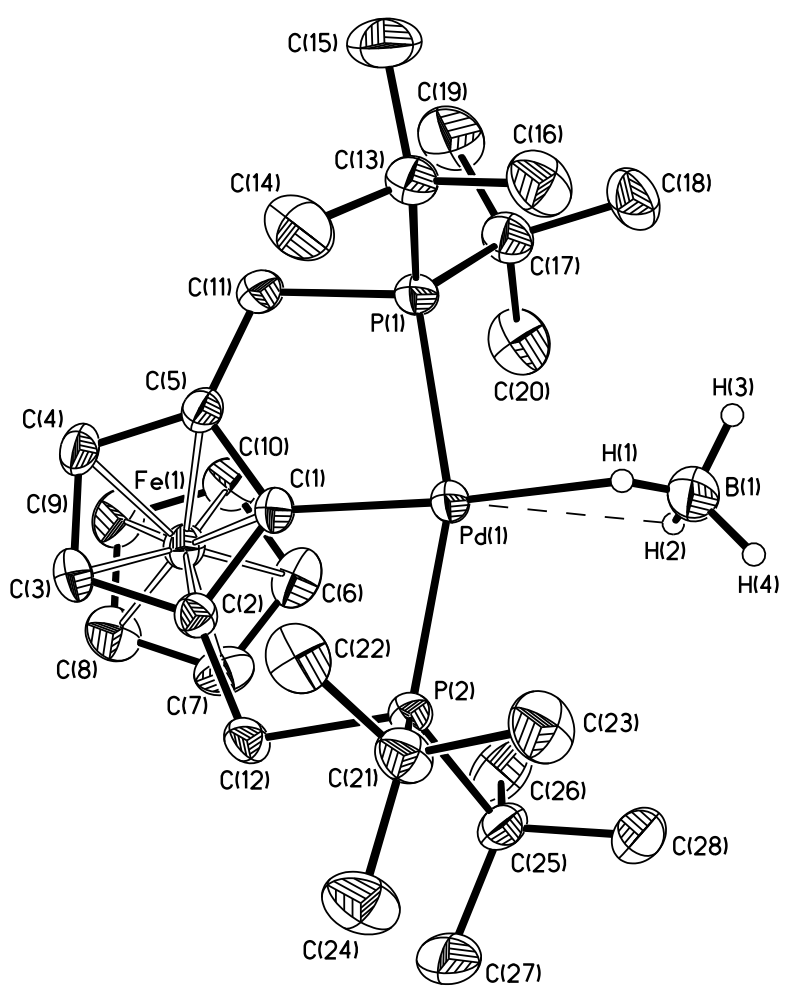

Figure 4. The molecular structure of $\mathbf{5 b}$. 
Table 2. Selected bond lengths $(\AA)$ and angles $\left(^{\circ}\right)$ in complex $\mathbf{5 b}$

\begin{tabular}{|c|c|c|c|}
\hline $\mathrm{Pd}(1)-\mathrm{P}(1)$ & $2.3526(9)$ & $\mathrm{P}(1)-\mathrm{C}(11)$ & $1.854(3)$ \\
\hline $\operatorname{Pd}(1)-P(2)$ & $2.3521(9)$ & $\mathrm{P}(2)-\mathrm{C}(12)$ & $1.861(3)$ \\
\hline $\operatorname{Pd}(1)-C(1)$ & $1.980(3)$ & $C(1)-C(2)$ & $1.433(4)$ \\
\hline $\operatorname{Pd}(1) \ldots \mathrm{B}(1)$ & $2.614(7)$ & $C(1)-C(5)$ & $1.424(4)$ \\
\hline $\operatorname{Pd}(1)-\mathrm{H}(1)$ & $2.00(4)$ & $C(2)-C(3)$ & $1.439(4)$ \\
\hline $\operatorname{Pd}(1) \ldots H(2)$ & $2.56(5)$ & $C(2)-C(12)$ & $1.499(4)$ \\
\hline $\mathrm{B}(1)-\mathrm{H}(1)$ & $0.92(4)$ & $C(3)-C(4)$ & $1.421(5)$ \\
\hline $\mathrm{B}(1)-\mathrm{H}(2)$ & $1.14(5)$ & $C(4)-C(5)$ & $1.424(4)$ \\
\hline $\mathrm{B}(1)-\mathrm{H}(3)$ & $0.94(5)$ & $C(5)-C(11)$ & $1.491(5)$ \\
\hline $\mathrm{B}(1)-\mathrm{H}(4)$ & $0.98(6)$ & & \\
\hline $\mathrm{C}(1)-\mathrm{Pd}(1)-\mathrm{P}(1)$ & $80.67(9)$ & $\mathrm{C}(2)-\mathrm{C}(1)-\mathrm{Pd}(1)$ & $125.2(2)$ \\
\hline $\mathrm{C}(1)-\mathrm{Pd}(1)-\mathrm{P}(2)$ & $80.97(9)$ & $C(1)-C(2)-C(3)$ & $107.4(3)$ \\
\hline $\mathrm{C}(1)-\mathrm{Pd}(1)-\mathrm{B}(1)$ & $173.6(3)$ & $C(1)-C(2)-C(12)$ & $120.8(3)$ \\
\hline $\mathrm{P}(1)-\mathrm{Pd}(1)-\mathrm{P}(2)$ & $160.72(3)$ & $\mathrm{C}(3)-\mathrm{C}(2)-\mathrm{C}(12)$ & $131.8(3)$ \\
\hline $\mathrm{P}(1)-\mathrm{Pd}(1)-\mathrm{B}(1)$ & $99.1(1)$ & $C(4)-C(3)-C(2)$ & $107.9(3)$ \\
\hline $\mathrm{P}(2)-\mathrm{Pd}(1)-\mathrm{B}(1)$ & $99.9(1)$ & $C(3)-C(4)-C(5)$ & $108.5(3)$ \\
\hline $\mathrm{Pd}(1)-\mathrm{H}(1)-\mathrm{B}(1)$ & $123(3)$ & $C(4)-C(5)-C(1)$ & $107.9(3)$ \\
\hline $\mathrm{C}(11)-\mathrm{P}(1)-\mathrm{Pd}(1)$ & $105.2(1)$ & $C(4)-C(5)-C(11)$ & $132.0(3)$ \\
\hline $\mathrm{C}(12)-\mathrm{P}(2)-\mathrm{Pd}(1)$ & $105.6(1)$ & $\mathrm{C}(1)-\mathrm{C}(5)-\mathrm{C}(11)$ & $120.0(3)$ \\
\hline $\mathrm{C}(5)-\mathrm{C}(1)-\mathrm{C}(2)$ & $108.3(3)$ & $\mathrm{C}(5)-\mathrm{C}(11)-\mathrm{P}(1)$ & $106.9(2)$ \\
\hline$C(5)-C(1)-P d(1)$ & $125.7(2)$ & $\mathrm{C}(2)-\mathrm{C}(12)-\mathrm{P}(2)$ & $106.2(2)$ \\
\hline
\end{tabular}




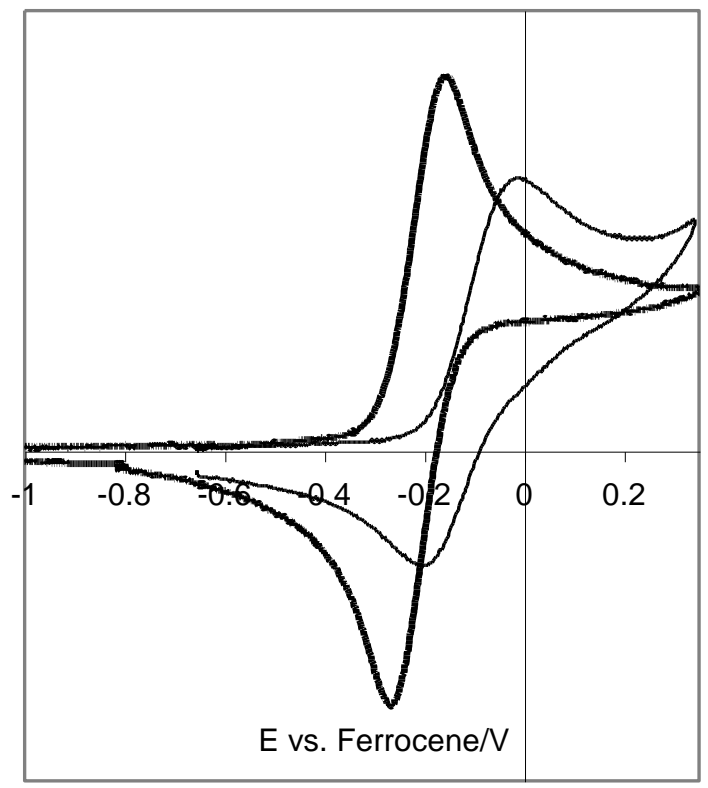

Figure 5. Cyclic voltammograms of compounds $\mathbf{2} \mathbf{b}$ (thinner line) and $\mathbf{3 b}$ (thicker line) in THF solution. Scan rate $=100 \mathrm{mV} \mathrm{s}^{-1}$. 
Table 3. Summary of crystal structure determination for complexes $\mathbf{3 a}, \mathbf{3 b}$ and $\mathbf{5 b}$.

\begin{tabular}{|c|c|c|c|}
\hline Compound & $3 \mathbf{a}$ & $3 \mathbf{b}$ & $5 \mathbf{b}$ \\
\hline formula & $\mathrm{C}_{24} \mathrm{H}_{39} \mathrm{ClP}_{2} \mathrm{FePd}$ & $\mathrm{C}_{28} \mathrm{H}_{47} \mathrm{ClP}_{2} \mathrm{FePd}$ & $\mathrm{C}_{28} \mathrm{H}_{51} \mathrm{BP}_{2} \mathrm{FePd}$ \\
\hline mol wt & 587.19 & 643.30 & 622.69 \\
\hline cryst color, habit & yellow prism & orange plate & orange prism \\
\hline cryst size, mm & $0.30 \times 0.20 \times 0.10$ & $0.20 \times 0.18 \times 0.04$ & $0.55 \times 0.40 \times 0.20$ \\
\hline cryst syst & Orthorhombic & Orthorhombic & Monoclinic \\
\hline space group & $P 2{ }_{1}{ }_{1}{ }_{1}$ & $P b c a$ & $P 2{ }_{1} / c$ \\
\hline temperature, $\mathrm{K}$ & 295(2) & 295(2) & 295(2) \\
\hline$a, \AA$ & $12.018(2)$ & $17.2290(6)$ & $10.977(1)$ \\
\hline$b, \AA$ & $14.031(4)$ & $16.4470(5)$ & $18.634(2)$ \\
\hline$c, \AA$ & $15.439(3)$ & $21.3131(7)$ & $15.632(2)$ \\
\hline$\beta$, deg & & & $109.312(2)$ \\
\hline$V, \AA^{3}$ & 2603(1) & $6039.4(3)$ & $3017.5(5)$ \\
\hline$Z$ & 4 & 8 & 4 \\
\hline$d_{\text {calc }}, \mathrm{g} / \mathrm{cm}^{3}$ & 1.498 & 1.415 & 1.371 \\
\hline$\mu(\operatorname{MoK} \alpha \lambda=0.71073 \AA), \mathrm{cm}^{-1}$ & 14.82 & 12.85 & 11.97 \\
\hline diffractometer & Enraf Nonius CAD4 & SMART 1000 CCD & SMART 1000 CCD \\
\hline scan technique & $\theta-5 / 3 \theta$ & $\omega$ and $\varphi$ & $\omega$ and $\varphi$ \\
\hline $2 \theta_{\max }, \operatorname{deg}$ & 56 & 56 & 60 \\
\hline reflectn collected & 3502 & 44813 & 28100 \\
\hline independent reflectn $\left(R_{\text {int }}\right)$ & 3502 & $7291(0.0767)$ & $8751(0.0435)$ \\
\hline Obsd reflectn $(I>2 \sigma(I))$ & 2588 & 3538 & 5266 \\
\hline$R_{1}^{\mathrm{a}}$ & 0.0362 & 0.0471 & 0.0440 \\
\hline$w R_{2}{ }^{\mathrm{b}}$ & 0.0776 & 0.1026 & 0.0928 \\
\hline
\end{tabular}

${ }^{\mathrm{a}} R_{l}=\Sigma\left|F_{o}-\right| F_{c}|| / \Sigma\left(F_{o}\right)$

${ }^{\mathrm{b}} w R_{2}=\left\{\Sigma\left[w\left(F_{o}{ }^{2}-F_{c}{ }^{2}\right)^{2}\right] / \Sigma w\left(F_{o}{ }^{2}\right)^{2}\right\}^{1 / 2}$ 


\section{References}

(1) van Koten, G. Pure Appl. Chem. 1989, 61, 1681.

(2) For reviews, see: (a) van der Boom, M.E., Milstein, D. Chem. Rev. 2003, 103, 1759. (b) Singleton, J.T. Tetrahedron. 2003, 59, 1837. (c) Albrecht, M., van Koten, G. Angew. Chem., Int. Ed. 2001, 40, 3750. (d) Jensen, C.M. J.Chem. Soc., Chem. Commun. 1999, 2443.

(3) Moulton, C.J., Shaw, B.L. J. Chem. Soc., Dalton Trans. 1976, 1020.

(4) van Koten, G., Jastrzebski, J.T.B.H. J. Mol. Catal. A: Chem. 1999, 146, 317.

(5) (a) Ohff, M., Ohff, A., van der Boom, M.E., Milstein, D. J. Am. Chem. Soc. 1997, 119, 11687. (b) Beletskaya, I.P., Chuchurjukin, A.V., Dijkstra, H.P., van Klink, G.P.M., van Koten, G. Tetrahedron Lett. 2000, 411075. (c) Morales-Morales, D., Redon, R., Yang, C., Jensen, C.M. J. Chem. Soc., Chem. Commun. 2000, 1619. (d) Morales-Morales, D., Grause, C., Kasaoka, K., Redon, R., Cramer, R.E., Jensen, C.M. Inorg. Chim. Acta. 2000, 300-302, 958. (e) Morales-Morales, D., Cramer, R.E., Jensen, C.M. J. Organomet. Chem. 2002, 654, 44.

(6) Bedford, R.B., Draper, S.M., Scully, P.N., Welch, S.L. New. J. Chem. 2000, 24, 745.

(7) (a) Gorla, F., Togni, A., Venanzi, L. Organometallics, 1994, 13, 1607. (b) Zhang, X., Longmire, J.M., Shang, M., Organometallics, 1998, 17, 4373.

(8) Dani, P., Karlen, T., Gossage, R.A., Gladiali, S., van Koten, G. Angew.Chem., Int. Ed. 2000, 39, 743.

(9) Yao, J., Wong, W.T., Jia, G. J.Organomet. Chem. 2000, 598, 228. 
(10) (a) Hanel, M.W., Oevers, S., Angermund, K., Kaska, W.C., Fan, H-J., Hall, M.B., Angew. Chem., Int. Ed. 2001, 40, 3596. (b) Mohammad, H.A.Y., Grimm, J.C., Eichele, K., Mack, H-G., Speiser, B., Novak, F., Quintanilla, M.G., Kaska, W.C., Mayer, H.A., Organometallics, 2002, 21, 5775. (c) Krogh-Jespersen, K., Czerw, M., Goldman, A.S. J. Mol. Catal. A: Chem. 2002, 189, 95. (d) Krogh-Jespersen, K., Czerw, M., Renkema, K.B., Achord, P.D., Goldman, A.S. J. Am. Chem. Soc. 2002, 124, 11404. (e) Liu, F., Goldman, A.S. J. Chem. Soc., Chem. Commun. 1999, 655. (f) Gupta, M., Hagen, C., Kaska, W.C., Flesher, R., Jensen, C.M., J. Chem. Soc., Chem. Commun. 1996, 2083. (g) Xu, W.-W., Rosini, G.P., Gupta, M., Jensen, C.M., Kaska, W.C., Krogh-Jespersen, K., Goldman, A.S. J.Chem. Soc., Chem. Commun. 1997, 2273.

(11) Koridze, A.A., Sheloumov, A.M., Kuklin, S.A., Lagunova, V.Yu., Petukhova, I.I., Dolgushin, F.M., Ezernitskaya, M.G., Macharashvili, A.A., Chedia, R.V. Russ. Chem. Bull., Int. Ed. 2002, 51, 1077.

(12) Farrington, E.F., Martinez-Viviente, E., Williams, B.S., van Koten, G., Brown, J.M. J. Chem. Soc., Chem. Commun. 2002, 308.

(13) (a) Sheloumov, A.M., Kuklin, S.A., Lagunova, V.Yu., Petukhova, I.I., Petrovskii, P.V., Koridze, A.A. In Modern Trends in Organometallic and Catalytic Chemistry, Book of Abstracts, Moscow, May 18-23, 2003; P21. (b) Sheloumov, A.M., Kuklin, S.A., Lagunova, V.Yu., Petukhova, I.I., Petrovskii, P.V., Koridze, A.A. XV ${ }^{\text {th }}$ FECHEM Conferens on Organometallic Chemistry, Book of Abstracts, Zurich, August 10-15, 2003; P 0267. (c) Koridze, A.A., Kuklin, S.A., Sheloumov, A.M., Kondrashov, M.V., Dolgushin, F.M., Peregudov, A.S., Petrovskii, P.V. Russ. Chem. Bull., Int. Ed. 2003, 52, 2607. (d) Koridze, A.A., Kuklin, S.A., Sheloumov, A.M., Kondrashov, M.V., Dolgushin, F.M., Ezernitskaya, M.G., Petrovskii, P.V., Vorontsov, E.V. Russ. Chem. Bull., Int. Ed. 2003, 52, 2610. 
(14) (a) Marks, T.J., Kolb, J.R. Chem. Rev. 1977, 77, 263. (b) Bommer, J.C., Morse, K.W. Inorg. Chem. 1980, 19, 587.

(15) (a) Kemmich, B.F.M., Marshall, W.J., Fagan, P.J., Hauptman, E., Bullock, R.M., Inorg. Chim. Acta. 2002, 330, 52. (b) Cross, R.J., Kennedy, A.K., Muir, K.W. J. Organomet. Chem. 1995, 487, 227. (c) Gorla, F., Venanzi, L.M., Albinati, A. Organometallics, 1994, 13, 43. (d) Morales-Morales, D., Cramer R.E., Jensen, C.M. J. Organomet. Chem. 2002, 654, 44. (e) Longmire, J.M., Zhang, X., Shang, M. Organometallics, 1998, 17, 4374.

(16) (a) Seligson, A.L., Trogler, W.C. Organometallics, 1993, 12, 738. (b) Haenel, M.W., Jakubik, D., Krüger, C., Betz, P. Chem. Ber. 1991, 124, 333. (c) Morales-Morales, D., Grause, C., Kasaoka, K., Redón, R., Cramer, R.E., Jensen, C.M. Inorg. Chim. Acta. 2000, 300-302, 958.

(17) (a) Kraatz, H.-B., Milstein, D. J. Organomet. Chem. 1995, 488, 223. (b) Steffey, B. D., Miedaner, A., Maciejewski-Farmer, M.L., Bernatis, P.R., Herring, A.M., Allured, V.S., Carperos, V., DuBois, D.L. Organometallics, 1994, 13, 4844.

(18) (a) Bau, R., Yuan, H.S.H., Baker, M.V., Field, L.D. Inorg. Chim. Acta, 1986, 114, L 27.(b) Baker, M.V., Field, L.D. J. Chem. Soc., Chem. Commun. 1984, 996.

(19) Yoshida, T., Adachi, T., Ueda, T., Akao, H., Tanaka, T., Goto, F. Inorg. Chim. Acta, 1995, 231,95 .

(20) (a) Tagusagawa, F., Fumagalli, A., Koetzle, T.F., Shore, S.G., Schmitkons, T., Fratini, A.V., Morse, K.W., Wei, C.-Y., Bau, R. J. Am. Chem. Soc. 1981, 103, 5165. (b) Fryzuk, M.D., Rettig, S.J., Westerhaus, A., Williams, H.D., Inorg. Chem. 1985, 24, 4316.

(21) Ghilardi, C.A., Midollini, S., Orlandini, A. Inorg. Chem. 1982, 21, 4096. 
(22) (a) Makhaev, V.D., Borisov, A.P., Lobkovskii, E.B., Semenenko, K.N. Izv. AN SSSR, Ser. Khim. 1980, 2614. (b) Lobkovskii, E.B., Antipin, M.Yu., Borisov, A.P., Makhaev, V.D., Semenenko, K.N., Struchkov, Yu.T. Koord. Khim. 1981, 7, 307.

(23) Jensen, J.A., Girolami, G.S. Inorg. Chem. 1989, 28, 2107.

(24) (a) Liang, F., Jakobsen, H., Schmalle, H.W., Fox, T., Berke, H. Organometallics, 2000, 19, 1950. (b) Höck, J., Jacobsen, H., Schmalle, H.W., Artus, G.R.J., Fox, T., Amor, J.I., Bäth, F., Berke, H. Organometallics, 2001, 20, 1533.

(25) Jensen, J.A., Wilson, S.R., Girolami, G.S. J. Am. Chem. Soc. 1988, 110, 4977.

(26) (a) Dapporto, P., Midollini, S., Orlandini, A., Sacconi, L. Inorg. Chem. 1976, 15, 2768.

(27) (a) Shimoi, M., Nagai, S.-I., Ichikawa, M., Kawano, Y., Katoh, K., Uruichi, M., Ogino, H. J. Am. Chem. Soc. 1999, 121, 11704. (b) Kakizawa, T., Kawano, Y., Shimoi, M. Organometallics, 2001, 20, 3211.

(28) (a) Sun, X.-Z., Grills, D.C., Nikiforov, S.M., Polyakoff, M., George, M.W. J. Am. Chem. Soc. 1997, 119, 7521. (b) Geftakis, S., Ball, G.E. J. Am. Chem. Soc. 1998, 120, 9953. (c) Evans, D.R., Drovetskaya, T., Bau, R., Reed, C.A., Boyd, P.D.W. J. Am. Chem. Soc. 1997, 119, 3633.

(29) (a) Diversi, P., Iacoponi, S., Ingrosso, G., Laschi, F., Lucherini, A., Zanello, P. $J$. Chem. Soc., Dalton Trans. 1993, 351. (b) Pedersen, A., Tilset, M. Organometallics, 1994, 13, 4887.

(30) (a) Maisela, L.; Crouch, A.; Darkwa, J.; Guzei, I., Polyhedron 2001, 20, (26-27), 31893200. (b) Grant, G.; Carter, S.; Russell, A.; Poullaos, I.; VanDerveer, D., J. Organometal. Chem. 2001, 637, 683-690. (c) Chen, G.; Ou, S.; Bai, Z.; Han, G.; Duan, C., Chin. J. Inorg. Chem. 2003, 19, (5), 501-505.

(31) Bickert, P., Hildebrandt, B., Hafner, K. Organometallics, 1984, 3, 653. 
(32) Kasahira, A.; Izumi, T.; Yoshida, Y.; Shimuzi, I. Bull. Chem Soc. Jpn. 1982, 55, 1901.

(33) Flack, H.D., Acta Cryst., 1983, A39, 876.

(34) Sheldrick, G.M., SHELXTL-97 V5.10, 1997, Bruker AXS Inc., Madison, WI-53719, USA. 